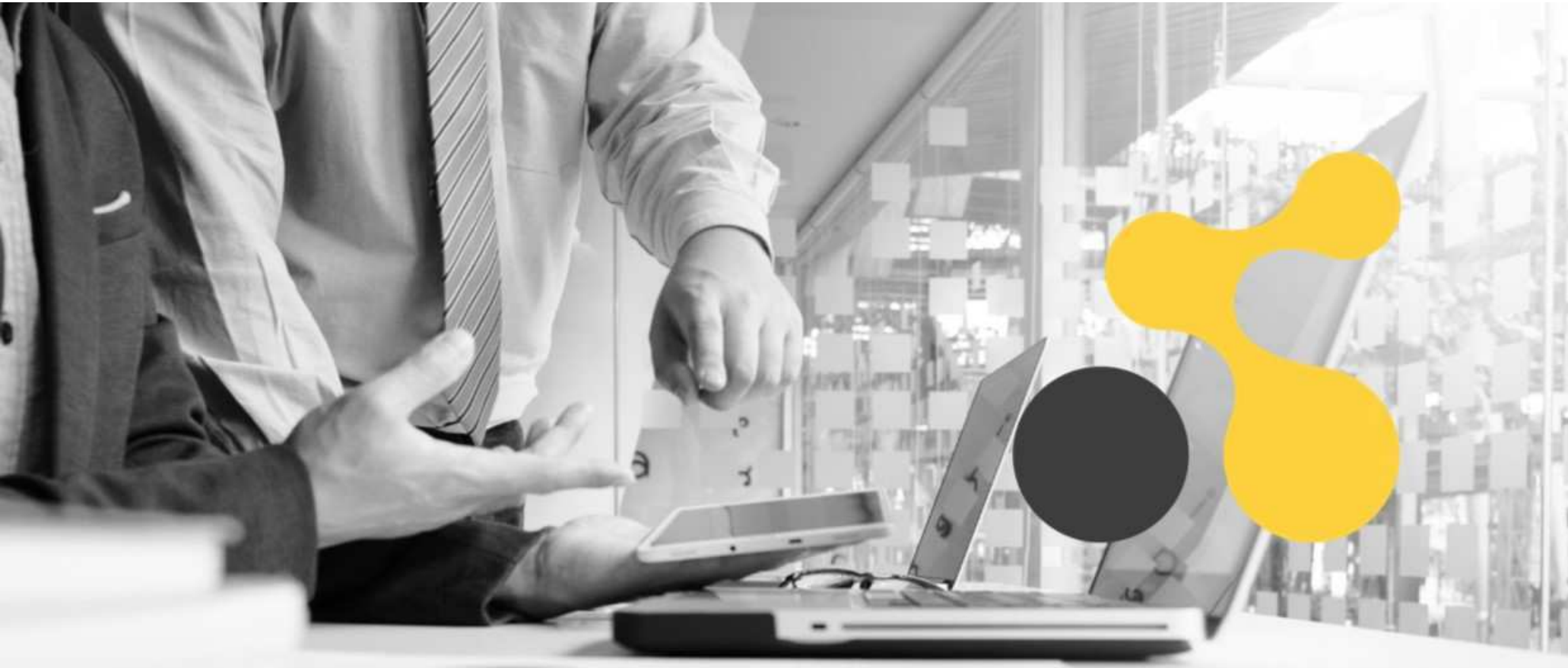

\title{
SCIPEDIA
}

\section{Material Cost Optimization and Quality Control Improvement of Building Construction}

Sori Tesema, Woyesa Ararsa, Jifara Chimdi, Emer Tucay Quezon ${ }^{12}$

1 Ambo University Hachalu Hundessa Institute of Technology

2 University of the Philippines Diliman

INFORMATION

Keywords:

Building construction

Cost control

Quality control

Material cost

Material quality

DOI:

https://doi.org/10.37896/jxu15.8/051

Published: 29/08/2021 


\title{
Material Cost Optimization and Quality Control Improvement of Building Construction
}

\author{
Sori Tesema ${ }^{\# 1}$, Woyesa Ararsa ${ }^{\# * 1}$, Jifara Chimdi ${ }^{\# 1}$ and Emer T. Quezon ${ }^{\# 1}$

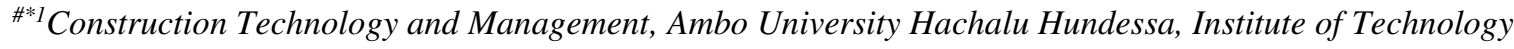 \\ Ambo University, Ambo City, Ethiopia, East Africa
}

\begin{abstract}
A building construction project cannot be completed successfully by only planning and scheduling. Project controlling that consists of project monitoring and updating, is the other critical stage. Construction materials cost and quality are becoming a severe problem in Ethiopia, especially in Ambo Town, where little consideration is given. The study tried to evaluate different factors affecting the materials cost and quality on building construction site, rank significant factors that are prevalently affecting the cost and quality of materials used for building projects from the point of view of the respondents and established a model to optimize materials cost and materials quality using multilinear regression method to come up with the model best fit. Purposive sampling was used, and 180 questionnaires were administered on building construction firms to analyze Material cost Optimization and quality control Improvement- Case Study of Ambo Town. To achieve this, a questionnaire survey containing factors affecting Building construction material cost and quality, which were identified by literature and Interview, was analyzed by using the Relative Importance Index, Pearson's correlation, and Multilinear regression model. Variables are statistically significant at $95 \%$ confidence level is assessed that all of the independent variables are positively related to Building Construction material cost and quality. The RII results showed that Material Wastage minimization $($ RII $=0.908)$, Proper workmanship $(\mathrm{RII}=\mathbf{0 . 8 5 9})$, Sufficient Training of workers/staff $(\mathrm{RII}=\mathbf{0 . 8 7 6})$, Proper forecasting of materials price in the market $(\mathrm{RII}=\mathbf{0 . 8 5 0})$, Using suitable, safe and secure storage $(\mathrm{RII}=\mathbf{0 . 8 8 6})$, Quality checking for each delivery of the aggregates to the site $(\mathrm{RII}=\mathbf{0 . 8 8 9})$, Cutting of materials $($ glass, tiles, plywood $)(\mathrm{RII}=\mathbf{0 . 8 7 0})$ and Design changes $(\mathrm{RII}=\mathbf{0 . 7 7 0})$ were ranked as the most significant among factors affecting building construction materials. Also, Two Multiple linear regression models were established for both dependent variables (material cost and material quality). The analysis results showed all independent variables were significant and had a strong positive relationship with dependent variables. The values of $R^{2}$ for the developed equations indicated 0.771 for material cost, and 0.777 for material quality. Hence, the basic recommendations such as planning and monitoring construction activities and inspection and verification of materials were anticipated to be exercised by key role players of the construction industry.
\end{abstract}

Keywords - Building construction, Cost control, Quality control, Material cost, Material quality.

\section{INTRODUCTION}

\subsection{Background of the study}

The construction sector is globally considered to be a basic industry on which the development of a country depends. To a great extent, the growth of a country and its development status is generally determined by the quality of its infrastructure and construction projects (Wasiu, A. B., Aliu, A. and Modupe, A., 2012). According to Shen and Tam, (2002) the construction sector plays a vital role in satisfying the needs of society as well as improving the quality of life.

Building construction Project cannot be completed successfully by only planning and scheduling. Project controlling that consists of project monitoring and updating is the other important stage to be carried out. Unless proper controlling is carried out, even a well-planned and scheduled construction system can lead to problems such as poor quality, delays and cost overruns. Patil (2011) identified that poor materials management can result in increased costs during construction. Efficient management of materials can result in substantial savings in project costs. According to Ioannou and Carr (1988), the cost of industrial buildings construction has risen dramatically in recent years. Most Building construction projects experience time delays and cost overruns while others experience low quality. Okpala and Aniekwu (1988) stated that the principal cause of high cost of construction is delay and cost overruns.

As defined by Neil J.M. (1982) Cost Control is the processing of raw information received from projects, operating divisions, and special staff division and relating this information to various project cost estimates and schedules for the purpose of presentation of results in the form of reports to all levels of company managerial, the client and outside agencies. On the other hand, Sadiwala (2006) addresses quality control as a very important and necessary function of material management to purchase the right quality of materials. However, quality control is the operational technique and activity that is used to fulfill requirements of quality; it is a system for insuring quality of output involving inspection, analysis and action to make required standards. In order to improve quality, an organization must consider the costs associated with achieving quality since the objective of continuous improvement programs is not only to meet customer requirements, but also to do it at the lowest possible cost. This can only be obtained by reducing the costs needed to achieve quality, and the reduction of these costs is only possible if they are identified and measured. Therefore, measuring and reporting the Cost of Quality (COQ) should be considered as an important issue for achieving quality excellence (Vaxevanidis, N.M., \& Petropoulos, G., 2008). 
There are many factors that have an impact on the direct cost, such as materials to be incorporated. Materials have two components: quantity and cost (Popescu, M.C., Phaobunjong, K., and Ovararin, N., 2001). One of the very important sections that should specify in the construction project management is managing and minimizing wastage of construction materials at construction projects. The successful execution of construction projects within given cost, time and quality, good handling of construction materials on construction site requires systematic planning and controlling of the construction works. Construction project refers to a high value, managing construction materials and special construction mission with minimizing waste performance objectives (Asmara Seyoum Joro, 2015). According to Omange and Udegbe (2000), the building construction sector constitutes material as an indispensable resource about 60percent of the total cost of the building. Similarly, Narimah Kasi (2013) stated construction materials are major components on any project with value 50$60 \%$.

Therefore, there is a need for efficient materials management in construction projects. This is because poor materials management will affect the overall construction time, quality and budget. Materials expenditure represents a major proportion of contract value. Hence, the control of purchasing, scheduling, delivery and handling of materials on site is an essential part of the control process (Cooke, B., Wiliams, P., 2004). Different studies described the importance of Building construction materials management for the success of the project. G. Kanimozhi (2014) defined construction material management as essential function that improves productivity in construction projects. Also Thomas, et al, (2005) identified Effective management of materials warrants their availability in adequate quantities and in time minimizing surplus materials at the end of the project and contributing to the success of the projects.

Achieving project completion within the estimated cost and quality are major criteria for success of any project in construction industry. Therefore, material cost and quality controls are the most important to be focused components of project management in building construction as it helps in keeping the project within its defined budget and demanded quality, unless otherwise it resulted in cost overrun and poor quality products. Hence, this research was studied on material cost optimization and quality control improvement on building construction project works.

\subsection{Statement of the Problem}

In recent times the construction industry becomes huge and it is one of the known industries that contribute a great role for the socio economic development of the country. The building construction project is complex and interconnected activity that involves different materials from its beginning to its completion. One of the big problems on most building sites is the large amount of materials wastage due to varying circumstances (Butler J. B., 1982).Resource inputs at the project site which produce outputs in the form of work include: men, materials, machinery and money. The success of a project depends upon the performance of these input resources when controlling costs (Hendrickson, 1998). Proper use and control of materials should be handled effectively for successful completion of a project whereas improper management and improper controlling of construction materials lead to cost overrun, low quality product and delays of the projects.

Presently Ethiopia Building construction industries are dynamic as a result of implementing major infrastructure projects. On the contrary, construction materials cost and quality are becoming a serious problem in Ethiopia especially in Ambo Town slight attention is given to such subject. The contractors and the design consultants are mainly concerned on how to control cost without any emphasis on waste control measures. Material waste is a major problem in the Ethiopian construction industry that has important implications both for the efficiency industry and for the environmental impact of construction projects due to lack of effective management and planning (Asmara Seyoum Joro, 2015). Most of the scholars agree that project quality in construction sector is affected by various internal and external factors (Bitew, 2019).

Arditi's and Gunaydin's (2004) findings indicated that the quality of the drawings and specifications received from the designer affect the quality in the design and construction phases, and consequently the quality of the constructed facility. According to Zubairu (2016) the main factors affecting quality management of building construction firms include; inadequacy of site personnel, poor material quality, poor quality of professionals and workmanship. Hence, the building project firms should alarmed on factors affecting construction materials cost and quality since materials accounted for a great percentage of the total cost of construction projects. Consequently, a critical control of materials on site along with proper construction management is expected to decrease cost and improve quality of construction projects.

In construction industry it's known that the cost and quality are the essential to measure the success of projects. The quality of building construction materials should be kept according to material standard and specification provided in the design together with efficient control of material management unless it affects the whole structure's quality and total cost of projects. The building construction projects in Ambo Town much vulnerable to this problem. Hence, this research was studied to fill this gap on the material cost control optimization and quality control improvement of building construction project works: the study in Ambo Town.

\subsection{Objectives of the Study}

\subsubsection{General Objective}

The general objective of this study was to assess the material cost optimization and quality control improvement of building construction: Case study of Ambo Town

\subsubsection{Specific Objectives}

The study addressed the following specific objectives.

- To identify the different factors affecting the materials cost and quality on building construction site. 
- To identify and rank the major factors that tend to affect the cost and quality of materials used for building project from the different groups of respondents.

- To establish a model to optimize materials cost and materials quality using multi-linear regression method

\subsection{Research Questions}

To address or to meet the research objectives, the research was focused on the following basic questions as follows:

1. What are the different factors affecting the materials cost and quality on building construction site?

2. Which major factors prevalently affect the cost and quality of materials used for building project from the point of views of the respondents?

3. How to optimize materials cost and materials quality using multi-linear regression method to come up with the model best fit?

\subsection{Significance of the Study}

Properly managed and controlled projects have great contribution to improve human society, productivity and for sustainability. The research is very important to improve the material cost and quality control of Ambo Town building construction. It's benefit to different stake holders such as clients, contractors and consultants. The research aim was also to fill the gap by adding literature and findings for similar related projects and to enhance ability and the practice of material cost and quality controlling of building construction projects.

In addition to the above significance other researchers use the findings as a reference for further research and the study findings also relevant input to the building construction stake holders to identify their strength and weakness on material cost and quality control.

\section{RESEARCH METHODOLOGY}

\subsection{Study Area}

Ambo is one of the reforming cities that is found in West Shewa Zone of Oromia National Regional State, 114 Kilometers to the west of Addis Ababa along the Addis Ababa - Nekemte highway. According to data from Ambo Structure Plan Studies, Ambo town was founded in 1888 E.C. and it became Municipal Administration Status in 1931. Geographically, the town is situated at $8^{0} 56^{\prime} 59^{\prime} \mathrm{N}$, and $37^{0} 47^{\prime} 55^{\prime} \mathrm{E}$.

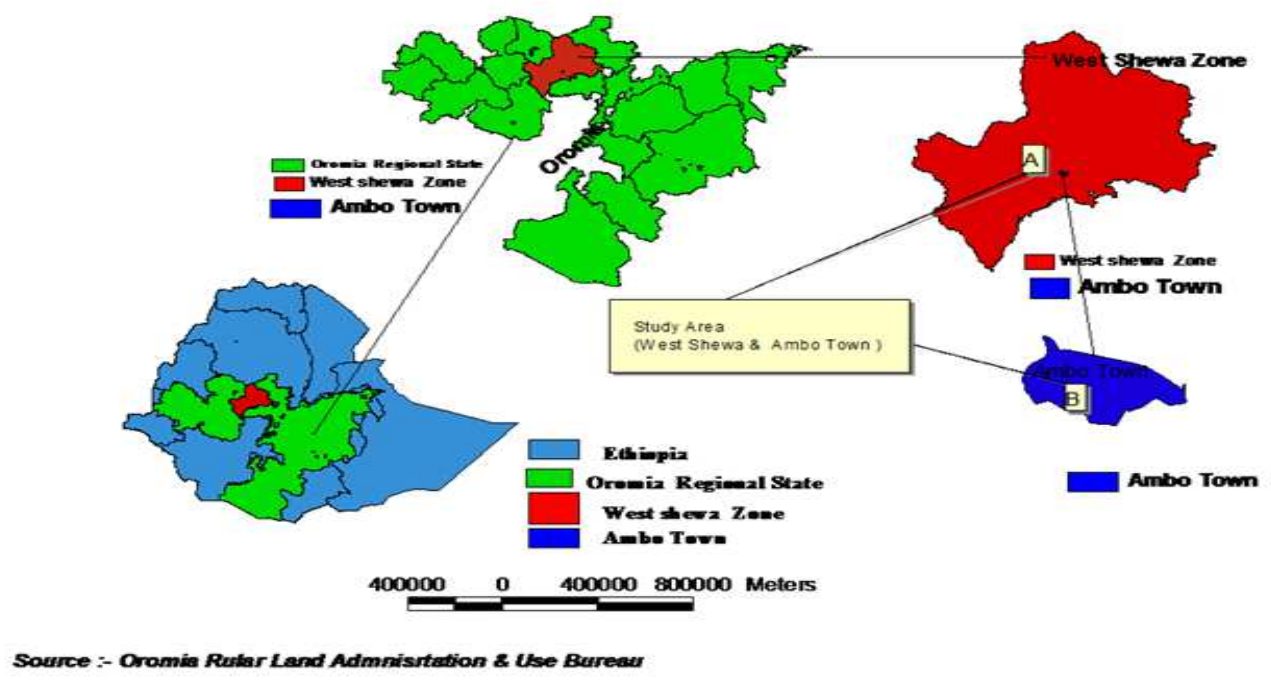

Fig. 1 Map of study area

\subsection{Data Survey and Analysis Methods}

Descriptive survey method was employed with the assumption that it could enable the researcher to reveal the assessment of material cost and quality control optimization on building construction site, a case study in Ambo Town. This method is appropriate because it helps in obtaining large variety of data related to the problem under the study. Quantitative and qualitative (mixed method) were employed to collect and analyze the data. Employing mixed approach enables the researcher to look from different perspectives and the context-based practice from participant's view. This method is chosen with the assumption that it helps to have data as it exists and to gather information related to the problem under study. The survey research design consisted of the questionnaire methods. It was allowed the researcher systematically collect data from a sample of population using questionnaire for making inferences and drawing conclusions.

For this study, samples were carefully selected to represent the characteristics of the population and the sample size was chosen using purposive sampling technique. It provided the researcher with the opportunity to generalize the findings of the study for the whole population so that the researcher can assess the building construction material cost optimization and quality control improvement for building construction sites in Ambo Town. 


\subsection{Population and Participants}

According to the data taken from Ambo Town Construction Office, there were 39 building construction Projects under construction in ambo town. The target populations were the key participants of the building construction projects which are client, contractor and consultants.

\subsection{Sampling techniques and Sample Size}

\subsubsection{Sampling techniques:}

This study used purposive sampling technique. The technique was preferred since it helped the researcher to focus on a limited number of informants that are selected from different projects experts to get the required information and to carry out the study in order to get optimal insight.

\subsubsection{Sample Size Determination:}

The three criteria to determine appropriate sample size are the level of precision, the level of confidence or risk, and the degree of variability in the attributes being measured. A critical component of sample size in the formula, was the estimation of variance in the primary variables of interest in the study. When estimating the variance of categorical (proportional) variable, Krejcie and Morgan (1970) recommended that researchers should use 0.50 as an estimate of the population proportion. This proportion will result in the maximization of variance, besides which will also produce the maximum sample size. Therefore, the required sample size is given as:

$$
n_{0}=\frac{(Z)^{2} * p q}{(d)^{2}}
$$

Where: $\boldsymbol{Z}$ is a value for the selected alpha level. The alpha level indicates the level of risk the researcher is willing to take that true Margin of error may exceed the acceptable margin of error) and $(\boldsymbol{p})(\boldsymbol{q})$ is estimate of variance $=0.25$ to produce maximum possible sample size, $\mathrm{d}$ is acceptable margin of error for proportion being estimated (error researcher is willing to take). Therefore, for a population of size $N$, the required initial sample size is $n_{0}$. However, since this sample size $n_{0}$ exceeds $5 \%$ of the population $\left(N^{*} 0.05=\alpha\right)$, Cochran's (1977) correction formula should be used to calculate the final sample size. These calculations are as follows:

$$
n=\frac{n_{0}}{1+\frac{n_{0}}{N}}
$$

Where: $\boldsymbol{N}$ is population size; $\boldsymbol{n}_{\mathbf{0}}$ is the required initial sample size according to Cochran's formula and $\boldsymbol{n}$ is required sample size if the initial sample is greater than $5 \%$ of population. Therefore, the minimum sample size employed should ben. For this study the sample size $n_{1}$ is selected using purposive Sampling technique. Applying the above formula:

$$
\begin{aligned}
& n_{0}=\frac{(Z)^{2} * p q}{(d)^{2}}=\frac{(1.96)^{2} *(0.5) *(0.5)}{(0.06)^{2}}=\frac{0.9604}{0.0036}=267 \\
& \text { Since } \frac{n_{0}}{N}>5 \% \text { it needs adjustment as follows; } \\
& n=\frac{267}{1+\frac{267}{390}}=158.49 \text { Approximately } 159 \text { samples }
\end{aligned}
$$

By adding $13 \%$ for unreturned questionnaires, that mean $0.13 * 159=20.67 \approx 21$, hence $159+21=180$ questionnaires were distributed for employers, contractors and consultants of Ambo town building construction project works.

\subsubsection{Study variables}

Independent variables Dependent variables

- Material usage(workmanship)

- Material Standard (specification fulfillment)

- Material management

- Material waste management

- Material price related factor

- Design effect

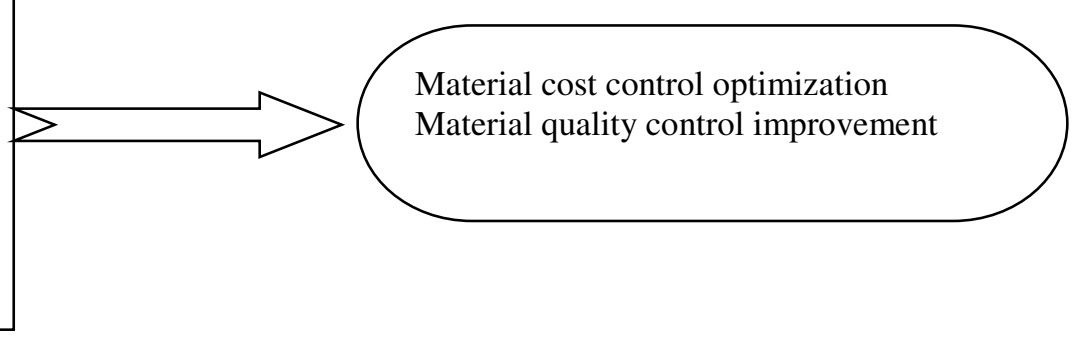

Fig. 2 Research variables

\subsubsection{Data Collection and Instruments}

The main tools used to gather the primary data from the primary sources mainly included questionnaire and interview. In this research, semi-structured interview and questionnaires were administrated as survey instruments. The data was collected 
mainly from primary sources through survey questionnaire in order to collect relevant data for the purpose of this study, and interview which enables the researcher to gain genuine information. Accordingly, the researcher has chosen a survey questionnaire method assuming that this is cost and time effective; data were analyzed and reduces biases since similar questions were distributed to each respondent. Secondly, interview was considered as chosen instrument incase respondents misunderstand relevant questionnaires.

Questionnaires have been prepared considering different factors which affects material cost and quality at building construction site in Ambo Town. Then, again the interviews of experienced participants were conducted since the responses contribute to the understanding of current building construction material cost and quality control on project works.

\section{4.5 Data Processing}

The research focused on material cost optimization and quality control improvement on selected building construction projects in Ambo Town. The study tried to evaluate, the different factors affecting the materials cost and quality on building construction site, ranked major factors that are prevalently affecting the cost and quality of materials used for building project from the point of view of the respondents and It established the model to optimize material cost and material quality using multi-linear regression method to come up with the model best fit.

To address the research objectives, data was collected from the concerned stakeholders using survey questionnaire, and interviews were conducted to different actors of building construction projects. Before the statistical analysis of the quantitative survey results, the screening of the data performed. Data screening included the descriptive statistics for all the variables, information about the missing data, linearity and normality, singularity editing, coding and classification. For the quantitative analysis of the data descriptive statistics such as percentage and frequency were used in order to meaningful analysis and interpretation of the research output. Moreover, inferential analysis such as Relative Importance Index, Pearson's product correlation and multi-linear regression were applied.

\subsubsection{Methods of data analysis}

The study employed both descriptive and inferential statistical tools of analysis to present and analyses the responses from the questionnaires survey. The quantitative data was coded and entered to SPSS Software version 20.

At first descriptive statistical tools were used aimed at describing and summarizing the data derived from the research questionnaires using tabulation and frequency distribution.

In calculating the Relative Importance Index, all factors were given equal weight but depend on the respondents rating. Accordingly, 5 point (weight) is given to the strongly agree, 4 point is given to agree, 3 point is neutral, 2 point is given to dis-agree and 1 point is given to strongly dis-agree. Based on this weight the Relative Importance Index (RII) is calculated as per the following formula:

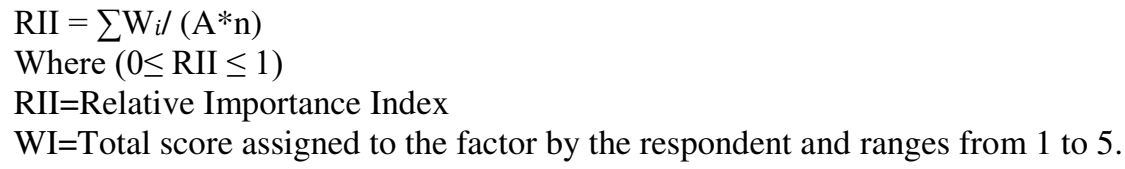

Where: Total point score $=$ Summation of all the ratings for a given factors (variables)

For Example: If 91 respondents said strongly agree, 55 respondents agree, 9 respondents neutral, 4 respondents dis-agree and 4 respondents said strongly dis-agree out of total 163 respondents, the total point score is calculated as: $91 * 5+55 * 4+9 * 3$ $+4 * 2+4 * 1=714, \mathrm{RII}=714 /(5 * 163)=0.876$

The next method was through the use of inferential statistical tools. This was to enable the study draw inferences on the sampled population of the study. Therefore, Pearson's Product Moment Correlation coefficient and Regression analysis were utilized. According to (Ho, 2006), Correlation is primarily concerned with finding out whether a relationship exists with determining its magnitude and direction. The values of the correlation coefficients vary between +1.00 and -1.00 . Both of these extremes represent perfect relationships between the variables, and 0.00 represents the absence of a relationship. On the other hand, Multiple Linear regression models were also established in the analysis. Multiple regression is a statistical technique through which one can analyze the relationship between a dependent or criterion variable and a set of independent or predictor variables. It was used to test the degree or level of the effects of independent variable (I.V) on the dependent variable (D.V). Two models were established in the study, i.e. Building Construction Material Cost Control Optimization, and Building Construction Material Quality Control Improvement. (Ho, 2006) stated that, as a statistical tool, Multiple regression is frequently used to achieve three objectives:

- To find the best prediction equation for a set of variables: i.e., given $\mathrm{X}$ and $\mathrm{Y}$ (the predictors), what is $\mathrm{Z}$ (the criterion variable)?

- To control for confounding factors to evaluate the contribution of a specific variable or set of variables, i.e., identifying independent relationships.

- To find structural relationships and provide explanations for seemingly complex multivariate relationships, such as is done in path analysis. 
The prediction equation is:

$$
Y^{\prime}=A+B 1 X 1+B 2 X 2+\ldots . B n X n
$$

Where: $\mathrm{Y}^{\prime}=$ the predicted dependent variable, $\mathrm{A}=$ constant, $\mathrm{B}=$ unstandardized regression coefficient, and $\mathrm{X}=\mathrm{value}$ of the predictor variable.

\section{RESULTS AND DISCUSSIONS}

\subsection{Introduction}

This part of the research deals with the analysis and discussion of the data compiled from the Interview and questionnaire. It includes the identification of different factors that affects building construction material cost and quality, rank and analysis of major factors that tends to affect the cost and quality of materials used and establish a model to optimize materials cost and quality using multi regression method.

The procedure used in analyzing the results was aimed at optimizing Building construction material cost and improving quality control, through identification of the relative impacts of the various factors that are responsible for building construction material cost and quality on building construction work under implementation, the case study in Ambo Town. The questionnaire was intended to give each respondent an opportunity to identify the factor that was likely to affects building construction material cost and quality in Ambo Town Building Construction projects under construction with the respondent's response "I strongly disagree", "Disagree", "Neutral/Not sure", "Agree" and "Strongly agree". Based on the respondents answer, the correlation of the identified major factors was conducted to rank the degree of the relationship and their impacts on dependent variables (Building construction material cost and quality).

Also multiple linear regressions were conducted to identify the significances, the directions and the strengths of effects of the independent variables had on Building construction material cost and quality. In addition to this, the Interview was also conducted for further assessment, to identify the major factors that were affecting the Building construction material cost and quality from the main three participants (Clients/Employers/, Contractors and Consultants) of Building construction industry, and to get their suggestion how to optimize Building construction material cost and quality control on building construction project works.

\subsection{General Background and Information of respondents}

\subsubsection{Type of respondents' Organization and Questionnaire Response Rate}

Detailed questionnaires were designed and disseminated for the Assessment Material Cost and Quality control optimization on building construction site of Ambo Town. In line with this purpose, questionnaires were distributed to major stakeholders in the industry such as Contractors, Employers and Consultants. A total 180 of questionnaires were distributed to contractors, consultants and Employers out of which, 168 questionnaires were filled and returned. One questionnaire from consultant and three questionnaires from contractor and one from client were rejected due to incompleteness. Hence, out of the 168 questionnaires 163 were found to be suitable for data analysis consisting of 43 (26.4\%) from the Employer, $16(9.8 \%)$ from consultants and $104(63.8 \%)$ from contractors. The overall valid response rate was $90.5 \%$ as shown in Table I below.

TABLE I

\section{QUESTIONNAIRE DISTRIBUTION}

\begin{tabular}{l|c|c|c}
\hline Classification & $\begin{array}{l}\text { Questionnaires } \\
\text { Distribution }\end{array}$ & No of valid Responses & $\begin{array}{l}\text { Percentage } \\
\text { Responses } \\
\text { distribution (\%) }\end{array}$ \\
\hline Contractor & 112 & 104 & $63.8 \%$ \\
\hline Employer & 50 & 43 & $26.4 \%$ \\
\hline Consultant & 18 & 16 & $9.8 \%$ \\
\hline Total & 180 & 163 & $100 \%$ \\
\hline
\end{tabular}

\section{Source: Author}

\subsubsection{Position of the Respondents}

Among the forty-three responses received from client/employer/, twenty-five (58.1\%) of them were lead engineers, supervisors and eighteen (41.9) were office engineers. Among the sixteen responses received from consultants, nine (56.3\%) of them were office engineers and seven (43.7\%) were site supervisors, and among the one hundred four responses received from contractors, twelve $(11.5 \%)$ of them were project managers, twenty- two $(21.1 \%)$ of them were office engineers, fourteen $(13.5 \%)$ of them were assistant office engineer, forty- two (40.4\%) of them were Site engineers and fourteen $(13.5 \%)$ of them were Quantity surveyors. 


\subsubsection{Experience, Educational Attainment and Field of Specialization of the Respondents}

The level of experience of the organization and respondents has a great role to the Credibility of the feedback and the reliability of the research as a whole. Figure 3 below revealed the respondents' working experience in the construction industry. The respondents 0 to 5 years have $38.65 \%$ ( 63), 6 to 10 years $44.79 \%(73)$, 11 to 15 years $11.04 \%$ ( 18) and 5.52 $\%$ ( 9) of the respondents have more 15 years work experience in building construction industry. The majority of respondents fall in the category of 6-10 years of experience. This could indicate that those filling questionnaires had relatively reasonable experience in the industry and their responses could be trusted.

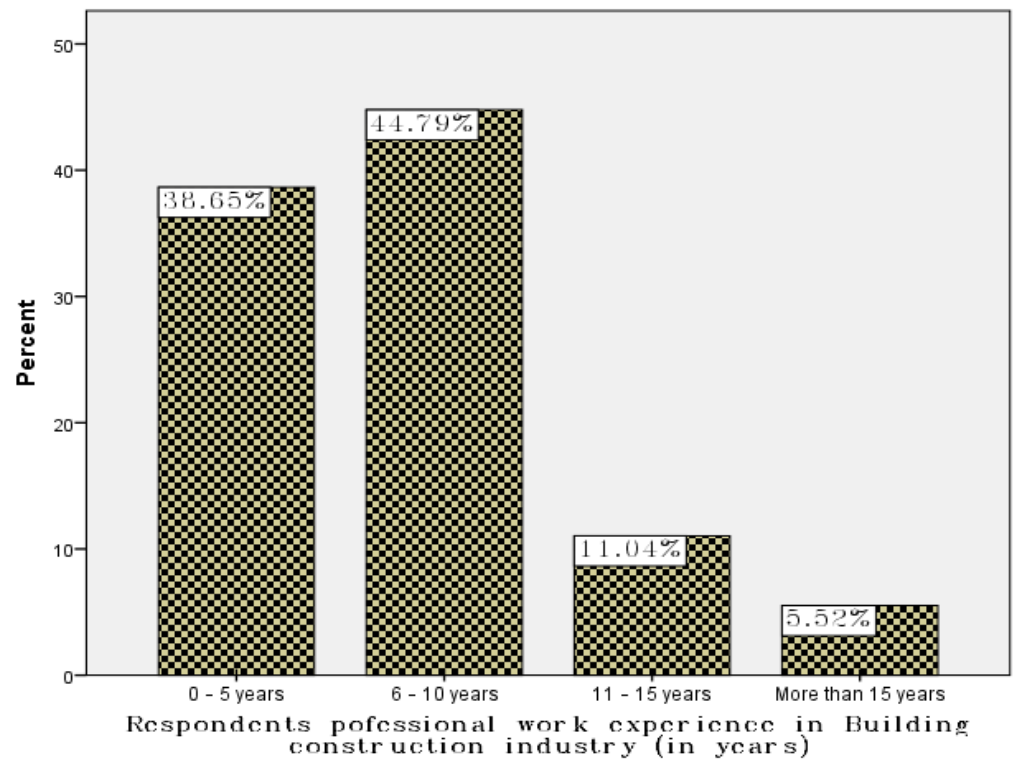

Fig. 3 Professional Work Experiences of respondent

\subsubsection{Building construction industry}

In regard to educational background of the respondents, as shown on Table II below Diploma or Advanced diploma, M.Sc. and B.Sc. degree holders' accounts to $8 \%, 11.7 \%$ and $80.4 \%$ of the valid respondents' number respectively. Also in terms of the respondent's field of specialization, about $60.12 \%$ were civil engineering, about $6.75 \%$ Structural Engineering and the remaining 33.13\% Construction Technology \& Management at the time of the survey in the organization.

TABLE II

EDUCATIONAL ATTAINMENT OF THE RESPONDENTS

\begin{tabular}{l|l|l}
\hline Educational attainment & Frequency & Percent \\
\hline Diploma/Advanced diploma & 13 & 8.0 \\
\hline Bsc. & 131 & 80.4 \\
\hline Msc. & 19 & 11.7 \\
\hline Total & 163 & 100.0 \\
\hline
\end{tabular}

\subsection{Analysis of Data from the Interview}

These interviews were made between selected Building construction industry practitioners who are currently involved in building construction projects focusing on their perceptions on building construction on material cost and quality control optimization. In total three interviews were conducted, namely with a senior project supervisor and follow up team leader, from the clients' group, a senior Project Supervisor from the consultants', and a senior project manager from the contractors' group as shown in Table III below. The interview aimed at discovering different factors that affects the material cost and quality of building construction project works and to seek recommendations to minimize their occurrence. 
TABLE III

INTERVIEW RESULTS

\begin{tabular}{|c|c|c|c|}
\hline Questions & Interviewee A & Interviewee B & Interviewee C \\
\hline 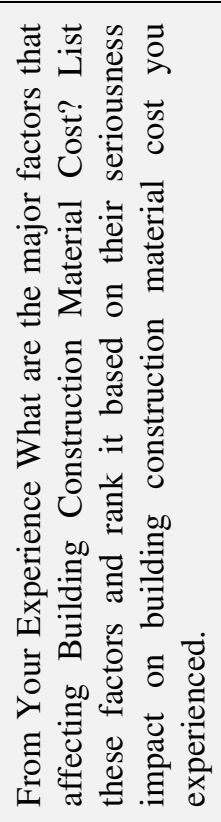 & $\begin{array}{l}\text { - There is Loss and } \\
\text { damage of materials } \\
\text { - Lack of experience } \\
\text { - } \text { Suddenly alteration of } \\
\text { materials price } \\
\text { - Improper estimation of } \\
\text { cost } \\
\text { - Lack of adequate skill in } \\
\text { material usage or } \\
\text { improper material usage } \\
\text { - Rework due to improper } \\
\text { - quality and mistakes } \\
\text { Design changes }\end{array}$ & 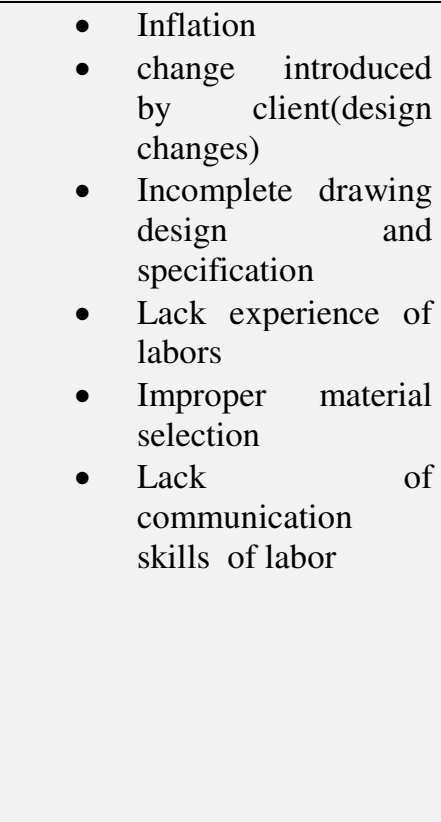 & 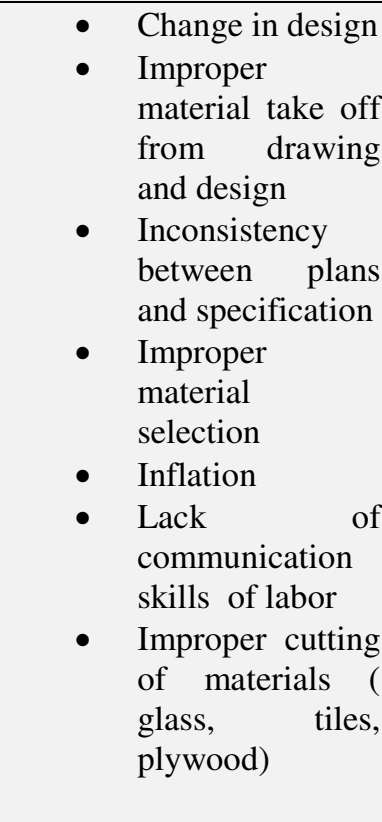 \\
\hline 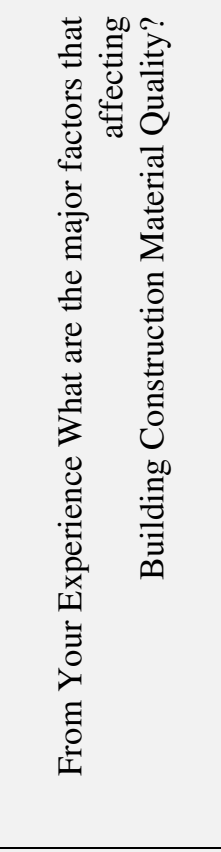 & $\begin{array}{l}\text { - Lack of regular quality } \\
\text { checking of each } \\
\text { material deliveries } \\
\text { - The steel reinforcement } \\
\text { stored for a long period } \\
\text { of time exposed to } \\
\text { weather } \\
\text { - Lack of quality training } \\
\text { and meeting } \\
\text { - Improper } \\
\text { size/dimension } \\
\text { materials } \\
\text { - Inadequate supervision } \\
\text { and Improper control } \\
\text { during storage } \\
\text { - Lack of experience }\end{array}$ & $\begin{array}{l}\text { - Inadequate } \\
\text { Inspection and } \\
\text { Verification of } \\
\text { materials quality } \\
\text { - Using unsuitable, } \\
\text { unsafe and unsecure } \\
\text { storage } \\
\text { - Inadequate training } \\
\text { for labors } \\
\text { - Lack } \\
\text { communication of } \\
\text { skills of labor } \\
\text { Exposing the steel } \\
\text { reinforcement to } \\
\text { weather for a long } \\
\text { period of time }\end{array}$ & $\begin{array}{l}\text { - } \begin{array}{l}\text { Inadequate } \\
\text { supervision in } \\
\text { usage } \\
\text { materials }\end{array} \\
\text { - } \begin{array}{l}\text { Lack of quality } \\
\text { training for }\end{array} \\
\text { labors } \\
\text { - Improper storage } \\
\text { space for bags of } \\
\text { cement } \\
\text { - Lack of adequate } \\
\text { skill in material } \\
\text { usage or } \\
\text { improper } \\
\text { material usage } \\
\text { - Lack of } \\
\text { inspection and } \\
\text { Verification of } \\
\text { materials quality }\end{array}$ \\
\hline 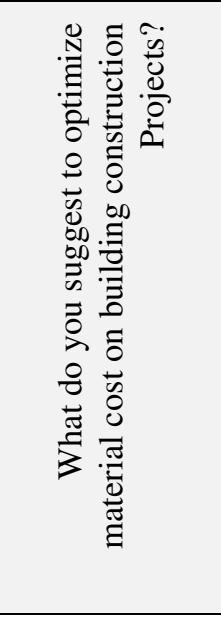 & 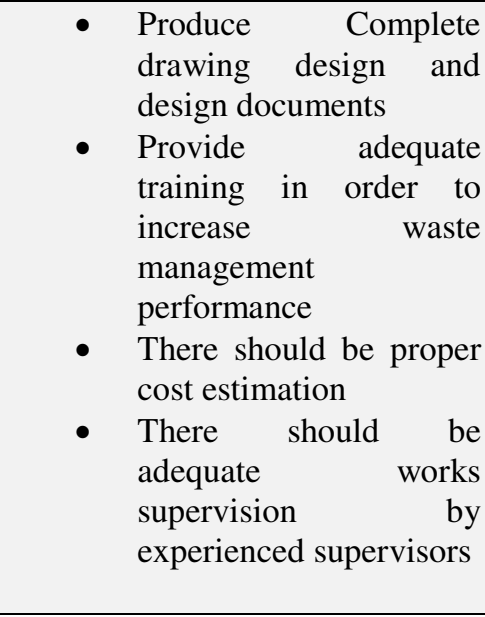 & $\begin{array}{l}\text { - Adequate market } \\
\text { data collection of } \\
\text { prices and } \\
\text { documentation } \\
\text { Design should be } \\
\text { complete at tender } \\
\text { stage. } \\
\text { - Develop } \\
\text { communication skill } \\
\text { of labors } \\
\text { - Proper material } \\
\text { selection }\end{array}$ & 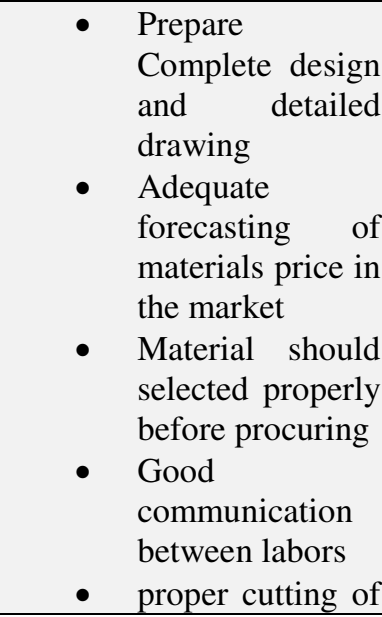 \\
\hline
\end{tabular}




\begin{tabular}{|c|c|c|c|}
\hline & & & $\begin{array}{l}\text { materials using } \\
\text { experienced } \\
\text { labors }\end{array}$ \\
\hline 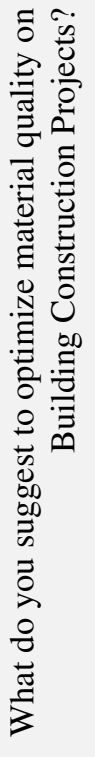 & $\begin{array}{l}\text { - Materials quality should } \\
\text { be checked/tested/ by } \\
\text { experienced person } \\
\text { The steel reinforcement } \\
\text { should not be stored for } \\
\text { a long period of time } \\
\text { exposed to weather } \\
\text { There should be } \\
\text { adequate of quality } \\
\text { training and meeting } \\
\text { Provide proper } \\
\text { size/dimension of } \\
\text { materials should be } \\
\text { There supervision } \\
\text { adequate control } \\
\text { and proper storage }\end{array}$ & $\begin{array}{l}\text { - Using suitable, safe } \\
\text { and secure storage } \\
\text { - Prepare training and } \\
\text { meeting for labors } \\
\text { on material quality } \\
\text { - Carry out adequate } \\
\text { supervision and } \\
\text { Verification of } \\
\text { materials quality } \\
\text { Communication } \\
\text { skills of labors } \\
\text { should be developed } \\
\text { Properly storing } \\
\text { steel reinforcement } \\
\text { and not expose to } \\
\text { weather for a long } \\
\text { period of time }\end{array}$ & 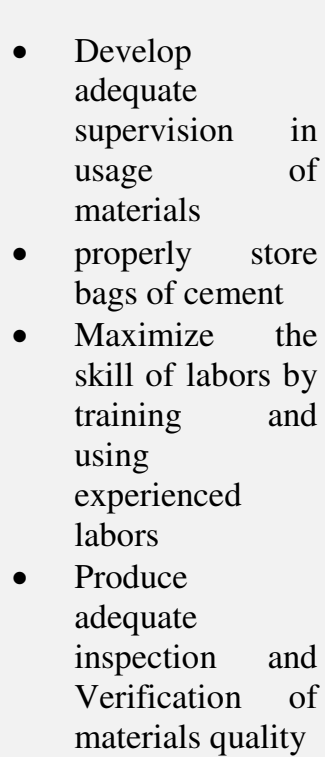 \\
\hline
\end{tabular}

\subsubsection{Findings from the Interview}

From the interview twenty (20) factors affecting building construction material cost in the first question, Sixteen (16) factors affecting Building Construction material quality in answering the second question, Fourteen(14) strategies to optimize Building Construction material cost answering identified in third question and Fourteen (14) strategies to optimize Building Construction material quality were identified. These variables were merged and checked if they were out of the literatures in order to include them in the questionnaire. But more of them with the same meaning were the domain of the variables identified from the literatures.

The findings from the interview revealed that there is Loss and damage of materials, Lack of experience, suddenly alteration of materials price, Improper cutting of materials (glass, tiles, plywood), Improper estimation of cost, Lack of adequate skill in material usage, Rework due to improper quality and mistakes, Design changes, Inflation, Incomplete drawing design and specification, Improper material selection, Lack of communication skills of labor and Inconsistency between plans and specification were the factors that affects material cost on building construction projects. The findings from the interview also revealed that there is Lack of regular quality checking of each material delivery, Exposing the steel reinforcement to weather for a long period of time, Lack of quality training and meeting, Improper size/dimension of materials, Inadequate supervision and Improper control during storage, Lack of experience, Inadequate Inspection and Verification of materials quality, Using unsuitable, unsafe and unsecure storage, Inadequate training for labors, Lack of communication skills of labor, and Improper storage space for bags of cement were the factors that affects material quality on Building construction project works.

The interviewee suggested that it is possible to Optimize Building construction material cost and quality with the most common strategies which always pointed out by experienced construction practitioners. According to the interviewee, Produce Complete drawing design and design documents, provide adequate training in order to increase waste management performance, Proper cost estimation, Adequate works supervision by experienced supervisors, Adequate market data collection of prices and documentation, develop communication skill of labors, Proper material selection and proper cutting of materials using experienced labors can Optimize material cost on Building construction building projects. The Interviewee also suggested that the possible strategies to Optimize Building construction material quality such as, Materials quality should be checked/tested/ by experienced person, The steel reinforcement should not stored for a long period of time exposed to weather, Adequate of quality training and meeting, Provide proper size/dimension of materials, Adequate supervision and proper control during storage, Using suitable, safe and secure storage, Develop Communication skills of labors and Develop adequate supervision in usage of materials can Optimize material quality of Building construction projects.

\subsection{Analysis of data from Questionnaires}

\subsubsection{Reliability}

According to Ho, (2008), Cronbach's alpha is a single correlation coefficient that is an estimate of the average of all the correlation coefficients of the items within a test. If alpha is high $(0.80$ or higher $)$, then this suggests that all of the items are reliable and the entire test is internally consistent. If alpha is low, then at least one of the items is unreliable, and must be identified via item analysis procedure. Table IV indicated the value of Cronbach's alpha in this study of 0.917 which revealed that all of the items of the research were reliable and the entire test was internally consistent. 


\section{TABLE IV \\ RELIABILITY STATISTICS}

\begin{tabular}{l|l}
\hline Cronbach's Alpha & N of Items \\
\hline .917 & 8 \\
\hline
\end{tabular}

\subsubsection{Relative Importance Index (RII)}

The rating of all the factors for degree of significance was based on the value of their respective Rrelative Importance Index (RII). Mbamali and Okotie (2012), Interpreted of the RII Values as follows:

- $\quad$ RII $<0.60$ item is assessed to have a low significance.

- $0.6 \leq \mathrm{RII}<0.80$ item assessed to have high significance.

- $\mathrm{RII} \geq 0.80$ item assessed to have very high significance.

\subsubsection{Factors affect Building construction Material Waste Management on project work}

Table V shows Factors affect Building construction Material Waste Management on project work. The factors with the values of RII $\geq 0.80$ are the highest ranked factors with very high significance because the relative important index (RII) is greater than 0.8. Based on this, Adequate Training of workers/staff on how to reduce waste of building construction materials is ranked highest with value of RII $=0.876$ while Waste management plans and using it is ranked second with the value of RII $=0.840$. Loss and damage of materials, learning from previous mistakes and Lack of enough Experience are the third, fourth and fifth ranked factors respectively with values of Relative Importance Index (RII) above 0.8 having very high significance. Waste management performance, Extra ordered materials discarded and sufficient places for material storage ranking sixth, seventh and eighth respectively with high significance values of RII.

Based on the RII results of the study, it can be seen that Adequate Training of workers/staff, Waste management plans and using and Loss and damage of materials it are the key factors affecting Building construction Material Waste Management on project work.

TABLE V

FACTORS AFFECT MATERIAL WASTE MANAGEMENT ON PROJECT WORK

\begin{tabular}{l|l|l|l}
\hline No & $\begin{array}{l}\text { Description of factors affect waste management on building } \\
\text { construction project works }\end{array}$ & $\begin{array}{l}\text { Relative } \\
\text { importance index }\end{array}$ & Rank \\
\hline 1 & $\begin{array}{l}\text { Adequate Training of workers/staff on how to reduce waste of } \\
\text { building construction materials }\end{array}$ & 0.876 & 1 \\
\hline 2 & Waste management plans and using it & 0.840 & 2 \\
\hline 3 & Loss and damage of materials & 0.829 & 3 \\
\hline 4 & Learning from previous mistakes & 0.828 & 4 \\
\hline 5 & Lack of enough Experience & 0.808 & 4 \\
\hline 6 & Waste management performance & 0.785 & 5 \\
\hline 7 & Extra ordered materials discarded & 0.770 & 6 \\
\hline 8 & Sufficient places for material storage & 0.703 & 7 \\
\hline
\end{tabular}

\subsubsection{Factors concerning building construction material Price}

Table VI presented the Factors concerning building construction material Price. Adequate forecasting of materials price in the market has been ranked the highest with the relative importance index (RII) of 0.85 while Inflation ranked second with the relative importance index (RII) of 0.835. Fluctuation in money exchange rates, Influence of Price escalation in the cost of construction materials on estimated cost and Following up the prices in the market and recording the variations of prices ranked third, fourth and fifth respectively with relative importance index (RII $\geq 0.8$ ) which is assessed to be of very high significance. While adequate market data collection of prices and documentation, improper estimation of cost and Influence of Suddenly alternation of price of materials on estimated cost sixth, seventh and eighth respectively with relative important index (RII) assessed to be of high significance.

As shown in the results below, adequate forecasting of materials price in the market and Inflation are very essential factors related material price that affect building construction material cost. 


\section{TABLE VI}

FACTORS CONCERNING MATERIAL PRICE

\begin{tabular}{l|l|l|l}
\hline No & $\begin{array}{l}\text { Description of factors concerning building construction } \\
\text { material Price }\end{array}$ & $\begin{array}{l}\text { Relative } \\
\text { importance index }\end{array}$ & Rank \\
\hline 1 & Adequate forecasting of materials price in the market & 0.850 & 1 \\
\hline 2 & Inflation & 0.835 & 2 \\
\hline 3 & Fluctuation in money exchange rates & 0.832 & 3 \\
\hline 4 & $\begin{array}{l}\text { Influence of Price escalation in the cost of construction } \\
\text { materials on estimated cost }\end{array}$ & 0.823 & 4 \\
\hline 5 & $\begin{array}{l}\text { Following up the prices in the market and recording the } \\
\text { variations of prices }\end{array}$ & 0.800 & 5 \\
\hline 6 & $\begin{array}{l}\text { Adequate market data collection of prices and } \\
\text { documentation. }\end{array}$ & 0.794 & 6 \\
\hline 7 & Improper estimation of cost & 0.777 & 7 \\
\hline 8 & $\begin{array}{l}\text { Influence of Suddenly alternation of price of materials on } \\
\text { estimated cost }\end{array}$ & 0.741 & \\
\hline
\end{tabular}

\subsubsection{Factors concerning building construction material Management on building construction projects works}

Table VII showed the Factors concerning building construction material Management at projects works. Using suitable, safe and secure storage and Congestion of sites were ranked the highest with the relative importance index (RII) of 0.886 , while Attention to weather condition ranked second with the relative importance index (RII) of 0.821. Adequate supervision and proper control during storage, Reporting the situation of materials in the project's store, Frequency of returning purchased materials, Identifying Material Schedule and Employment of store keeper and security personnel were ranked third, fourth, fifth, sixth and seventh respectively with relative importance index which is assessed to be of high significance. As shown in the results below, Using suitable, safe and secure storage and Congestion of sites are very essential factors related Management at projects works that affect building construction material cost and quality on building construction sites.

\section{TABLE VII}

\section{FACTORS CONCERNING MATERIAL MANAGEMENT ON SITE}

\begin{tabular}{l|l|l|l}
\hline No & $\begin{array}{l}\text { Description of factors concerning building construction material } \\
\text { Management on projects works }\end{array}$ & $\begin{array}{l}\text { Relative } \\
\text { importance } \\
\text { index }\end{array}$ & Rank \\
\hline 1 & Using suitable, safe and secure storage & 0.886 & 1 \\
\hline 2 & Congestion of sites & 0.866 & 1 \\
\hline 3 & Attention to weather condition & 0.821 & 2 \\
\hline 4 & Adequate supervision and proper control during storage & 0.790 & 3 \\
\hline 5 & Reporting the situation of materials in the project's store & & 4 \\
\hline 6 & Frequency of returning purchased materials & 0.788 & 5 \\
\hline 7 & Identifying Material Schedule & 0.735 & 6 \\
\hline 8 & Employment of store keeper and security personnel & 0.723 & 7 \\
\hline 9 & Controlling over-ordering and purchasing & 0.708 & 8 \\
\hline 10 & Daily recording of using materials in the project & 0.681 & 9.548 \\
\hline
\end{tabular}




\subsubsection{Factors Building construction material standard (specification) controlling on building construction fields}

Table VIII showed the Factors concerning material standard (specification) controlling on building construction fields. Quality checking for each delivery of the aggregates to the site from the sources has been ranked the highest with the relative importance index (RII) as 0.889 while Inspection and Verification of materials quality ranked second with the relative importance index (RII) of 0.856. The steel reinforcement stored for a long period of time exposed to weather, Quality training and meeting and adequate supervision in usage of materials ranked third, fourth and fifth respectively with relative importance index ( $\mathrm{RII} \geq 0.8$ ) which is assessed to be of very high significance. Tightly covered storage space for bags of Cement, The delivered materials does comply with the required specifications, Testing by a certified technicians and Proper size/dimension of materials were sixth, seventh, eighth and ninth respectively with relative important index (RII) assessed to be of high significance and only Assurance of quality from suppliers (Mill Test Certificate) was ranked tenth with low significance of RII.

As shown in the results below, Quality checking for each delivery of the aggregates to the site from the sources and Inspection and Verification of materials quality are very essential factors related material standard (specification) controlling on building construction fields that affects building construction material quality.

\section{TABLE VIII}

\section{FACTORS AFFECT MATERIAL STANDARD (SPECIFICATION)}

\begin{tabular}{l|l|l|l}
\hline No & $\begin{array}{l}\text { Description of factors concerning building construction material } \\
\text { standard (specification) controlling on building construction } \\
\text { fields }\end{array}$ & $\begin{array}{l}\text { Relative } \\
\text { importance } \\
\text { index }\end{array}$ & Rank \\
\hline 1 & $\begin{array}{l}\text { Quality checking for each delivery of the aggregates to the site } \\
\text { from the sources }\end{array}$ & 0.889 & 1 \\
\hline 2 & Inspection and Verification of materials quality & 0.856 & 2 \\
\hline 3 & $\begin{array}{l}\text { The steel reinforcement stored for a long period of time exposed } \\
\text { to weather }\end{array}$ & 0.826 & 3 \\
\hline 4 & Quality training and meeting & 0.822 & 4 \\
\hline 5 & $\begin{array}{l}\text { Adequate supervision in usage of materials } \\
\text { Tightly covered storage space for bags of Cement }\end{array}$ & 0.805 & 5 \\
\hline 7 & $\begin{array}{l}\text { The delivered materials do comply with the required } \\
\text { specifications }\end{array}$ & 0.791 & 6 \\
\hline 8 & Testing by a certified technicians & 0.755 & 7 \\
\hline 9 & Proper size/dimension of materials & 0.732 & 8 \\
\hline 10 & Assurance of quality from suppliers(Mill Test Certificate) & 0.510 & 10 \\
\hline
\end{tabular}

\subsubsection{Factors concerning Building construction material usage (workmanship)}

Table IX depicted the Factors concerning material usage (workmanship). Poor cutting of materials (glass, tiles, plywood) has been ranked the highest with the relative importance index (RII) as 0.870 while Rework due to improper quality and mistakes ranked second with the relative importance index (RII) of 0.827. Inadequate skill in utilization of materials, communication skills of labor and labors experience ranked third, fourth and fifth respectively with relative importance index $(\mathrm{RII} \geq 0.8)$ which is assessed to be of very high significance. Poor material selection, Delivery materials with wrong dimension and quantities, Lack of care in transporting construction materials, and Poor cutting of materials (glass, tiles, plywood) were ranked sixth, seventh, eighth, ninth and tenth respectively with relative importance index which is assessed to be of high significance.

As shown in the results below, adequate training or workshop for labors and Rework due to improper quality and mistakes are very essential factors related to Building construction material usage (workmanship). 


\section{FACTORS AFFECT MATERIAL USAGE (WORKMANSHIP)}

\begin{tabular}{l|l|l|l}
\hline No & $\begin{array}{l}\text { Description of factors concerning building construction material } \\
\text { usage (workmanship) }\end{array}$ & $\begin{array}{l}\text { Relative } \\
\text { importance } \\
\text { index }\end{array}$ & Rank \\
\hline 1 & Poor cutting of materials ( glass, tiles, plywood) & 0.870 & 1 \\
\hline 2 & Rework due to improper quality and mistakes & 0.827 & 2 \\
\hline 3 & Inadequate skill in utilization of materials & 0.811 & 3 \\
\hline 4 & Communication skills of labor & 0.809 & 4 \\
\hline 5 & Labors experience & 0.801 & 5 \\
\hline 6 & Material selection & 0.780 & 6 \\
\hline 7 & Delivery materials with wrong dimension and quantities & 0.773 & 7 \\
\hline 8 & Lack of care in transporting construction materials & 0.745 & 8 \\
\hline 9 & Motivation System Labors & 0.759 & 9 \\
\hline 10 & Preparing Workshop for labors & 0.736 & 10 \\
\hline
\end{tabular}

\subsubsection{Factors concerning Building construction material Design effects on construction works}

Table X indicated the Factors concerning building construction Design effects on construction material. Design changes (change introduced by client) has been ranked $1^{\text {st }}$ as with the relative importance index (RII) of 0.770 while Design conformance to codes and standards ranked second with the relative importance index (RII) of 0.767. Complete drawing design and specification, Completeness and consistency of design documents, Consistency between plans and specification, Specification for all necessary tests of material ,Proper schedule preparation, Bill of quantity is detailed and accurate, Drawings are prepared in details and Proper material takeoff from drawing and design were third, fourth , fifth , sixth , seventh, eighth, ninth and tenth respectively with the values of Relative index (RII) assessed to be high significance.

As presented on the results below Design changes (change introduced by client) and Design conformance to codes and standards are factors need more consideration.

TABLE X DESIGN FACTORS ON CONSTRUCTION MATERIAL

\begin{tabular}{l|l|l|l}
\hline No & $\begin{array}{l}\text { Description of factors concerning building construction Design } \\
\text { effects }\end{array}$ & $\begin{array}{l}\text { Relative } \\
\text { importance } \\
\text { index }\end{array}$ & Rank \\
\hline 1 & Design changes (change introduced by client) & 0.770 & 1 \\
\hline 2 & Design conformance to codes and standards & 0.767 & 2 \\
\hline 3 & Complete drawing design and specification & 0.755 & 3 \\
\hline 4 & Completeness and consistency of design documents & 0.752 & 4 \\
\hline 5 & Consistency between plans and specification & 0.746 & 5 \\
\hline 6 & Specification for all necessary tests of material & 0.742 & 6 \\
\hline 7 & Proper schedule preparation & 0.740 & 7 \\
\hline 8 & Bill of quantity is detailed and accurate & 0.730 & 8 \\
\hline 9 & Drawings are prepared in details & 0.729 & 9 \\
\hline 10 & Proper material takeoff from drawing and design & 0.723 & 10 \\
\hline
\end{tabular}




\subsubsection{Factors concerning Building Construction Material Cost and Factors concerning Building Construction Material quality}

Table XI below showed the Factors concerning Material Cost Optimization. Material Wastage minimization has been ranked the highest (RII=0.908) while Planning and monitoring construction activities is the second ranked with (RII $=$ 0.867). Proper workmanship, completing project within estimated budget, Conducting Material management as scheduled and Design effects were ranked third, fourth, fifth and sixth respectively with relative importance index (RII $\geq 0.8$ ) which is assessed to be of very high significance while Proper material utilization and Escalation of material prices ranked seventh and eighth with high significance value of RII.

Also Table XI below shows Factors concerning Material quality control. Planning and monitoring construction activities has been ranked the highest value of Relative Importance Index (RII=0.908) while Proper workmanship is the second ranked with $(\mathrm{RII}=0.867)$. Satisfaction of Clients and Specification compliance of materials were ranked third and fourth respectively with very high significance values of RII while Design effects ranked fifth with high significance value of RII.

According to the study of Zubairu (2015) on Assessment of quality management practices of building construction firms in Abuja, Nigeria, similar results were confirmed on some similar above factors that affects of achieving construction quality delivery such as: Inadequacy of site personnel $(\mathrm{RII}=0.87)$, certification of material $(\mathrm{RII}=0.87)$ and inadequate project control $(\mathrm{RII}=0.86)$ are the most important challenges faced by firms in achieving quality delivery in building construction projects. Also Zubairu (2015) and Quezon (2020) identified: on site supervision of construction process (RII=0.87), education of employees on quality standards ( $\mathrm{RII}=0.84)$, constant quality appraisal by firms $(\mathrm{RII}=0.84)$, conformance to relevant quality standards $(\mathrm{R}=0.83)$ and customer satisfaction $(\mathrm{R}=0.81)$ would enhance the quality management and improve construction service delivery.

\section{TABLE XI}

\section{FACTORS AFFECTS MATERIAL COST AND MATERIAL QUALITY}

\begin{tabular}{l|l|l|l}
\hline No & $\begin{array}{l}\text { Description of factors concerning building construction Material } \\
\text { Cost Optimization }\end{array}$ & $\begin{array}{l}\text { Relative } \\
\text { importance } \\
\text { index }\end{array}$ & Rank \\
\hline 1 & Material Wastage minimization & 0.908 & 1 \\
\hline 2 & Planning and monitoring construction activities & 0.867 & 2 \\
\hline 3 & proper workmanship & 0.859 & 3 \\
\hline 4 & The project completed within estimated budget & 0.838 & 4 \\
\hline 5 & Conducting Material management as scheduled & 0.810 & 5 \\
\hline 6 & Design effects & 0.805 & 6 \\
\hline 7 & Proper material utilization & 0.761 & 7 \\
\hline 8 & Escalation of material prices & 0.737 & 8 \\
\hline No & $\begin{array}{l}\text { Description of factors concerning building construction Material } \\
\text { quality Optimization }\end{array}$ & $\begin{array}{l}\text { Relative } \\
\text { importance } \\
\text { index }\end{array}$ & Rank \\
\hline 1 & Planning and monitoring construction activities & 0.867 & 1 \\
\hline 2 & Proper workmanship & 0.859 & 2 \\
\hline 3 & Satisfaction of Clients & 0.817 & 3 \\
\hline 4 & Specification compliance of materials & 0.810 & 4 \\
\hline 5 & Proper material utilization & 0.761 & 5 \\
\hline
\end{tabular}

\subsubsection{Pearson's Product Moment Correlation coefficient}

According to Ahmed (2015) Correlation is primarily concerned with find out whether a relationship exists with determining its magnitude and direction. When two variables vary together, such as loneliness and depression, they are said to be correlated. Accordingly, co relational studies are attempts to find the extent to which two or more variables are related. In this study, Pearson's Product Moment Correlation coefficient was used to determine whether there is significant relationship between independent variables and dependent variables. The following section presents the result of Pearson's Product Moment Correlation on the relationship between variables.

The values of the correlation coefficients vary between +1.00 and -1.00 . Both of these extremes represent perfect relationships between the variables, and 0.00 represents the absence of a relationship. Positive relationship means that individuals obtaining high scores on one variable tend to obtain high scores on a second variable. The converse is also true, 
i.e., individuals scoring low on one variable tend to score low on a second variable. A negative relationship means that individuals scoring low on one variable tend to score high on a second variable. Conversely, individuals scoring high on one variable tend to score low on a second variable (Ho, 2006). The correlation is a parameter of the bivariate normal distribution. This distribution is used to describe the association between two variables. This association does not include a cause and effect statement. That is, the variables are not labeled as dependent and independent. One does not depend on the other.

TABLE XII

FIRST PEARSON'S CORRELATION RESULTS ANALYSIS OF VARIABLES

\begin{tabular}{|c|c|c|c|c|c|c|c|}
\hline & & $\begin{array}{l}\text { Material } \\
\text { Waste } \\
\text { Management }\end{array}$ & $\begin{array}{l}\text { Material } \\
\text { Price related } \\
\text { factor }\end{array}$ & $\begin{array}{l}\text { Material } \\
\text { Management }\end{array}$ & $\begin{array}{l}\text { Workmanshi } \\
\text { p }\end{array}$ & $\begin{array}{l}\text { Design } \\
\text { Effects }\end{array}$ & $\begin{array}{l}\text { Material } \\
\text { Cost }\end{array}$ \\
\hline \multirow{3}{*}{\begin{tabular}{l|} 
Material \\
Waste \\
Management
\end{tabular}} & Pearson Correlation & 1 & $.380^{* *}$ & $.461^{* *}$ & $.490^{* *}$ & $.381^{* *}$ & $.532^{* *}$ \\
\hline & Sig. (2-tailed) & & .000 & .000 & .000 & .000 & .000 \\
\hline & $\mathrm{N}$ & 163 & 163 & 163 & 163 & 163 & 163 \\
\hline \multirow{3}{*}{$\begin{array}{l}\text { Material Price } \\
\text { related factor }\end{array}$} & Pearson Correlation & $380^{* *}$ & 1 & $.626^{* *}$ & $.621^{* *}$ & $.461^{* *}$ & $.658^{* *}$ \\
\hline & Sig. (2-tailed) & .000 & & .000 & .000 & .000 & .000 \\
\hline & $\mathrm{N}$ & 163 & 163 & 163 & 163 & 163 & 163 \\
\hline \multirow{3}{*}{$\begin{array}{l}\text { Material } \\
\text { Management }\end{array}$} & Pearson Correlation & $.461^{* *}$ & $.626^{* *}$ & 1 & $.940^{* *}$ & $.617^{* *}$ & $.820^{* *}$ \\
\hline & Sig. (2-tailed) & .000 & .000 & & .000 & .000 & .000 \\
\hline & $\mathrm{N}$ & 163 & 163 & 163 & 163 & 163 & 163 \\
\hline \multirow{3}{*}{ Workmanship } & Pearson Correlation & $.490^{* *}$ & $.621^{* *}$ & $.940^{* *}$ & 1 & $.622^{* *}$ & $.825^{* *}$ \\
\hline & Sig. (2-tailed) & .000 & .000 & .000 & & .000 & .000 \\
\hline & $\mathrm{N}$ & 163 & 163 & 163 & 163 & 163 & 163 \\
\hline \multirow{3}{*}{ Design Effects } & Pearson Correlation & $.381^{* *}$ & $.461^{* *}$ & $.617^{* *}$ & $.622^{* *}$ & 1 & $.680^{* *}$ \\
\hline & Sig. (2-tailed) & .000 & .000 & .000 & .000 & & .000 \\
\hline & $\mathrm{N}$ & 163 & 163 & 163 & 163 & 163 & 163 \\
\hline \multirow{3}{*}{$\begin{array}{l}\text { Material } \\
\text { Cost }\end{array}$} & Pearson Correlation & $.532^{* *}$ & $.658^{* *}$ & $.820^{* *}$ & $.825^{* *}$ & $.680^{* * *}$ & 1 \\
\hline & Sig. (2-tailed) & .000 & .000 & .000 & .000 & .000 & \\
\hline & $\mathrm{N}$ & 163 & 163 & 163 & 163 & 163 & 163 \\
\hline
\end{tabular}

TABLE XIII

SECOND PEARSON'S CORRELATION RESULTS ANALYSIS OF VARIABLES

\begin{tabular}{|c|c|c|c|c|c|}
\hline & & Specification & Workmanship & $\begin{array}{l}\text { Material } \\
\text { Management }\end{array}$ & Material Quality \\
\hline \multirow{3}{*}{ Specification } & Pearson Correlation & 1 & $.611^{* *}$ & $.583^{* *}$ & $.806^{* *}$ \\
\hline & Sig. (2-tailed) & & .000 & .000 & .000 \\
\hline & $\mathrm{N}$ & 163 & 163 & 163 & 163 \\
\hline \multirow{3}{*}{ Workmanship } & Pearson Correlation & $.611^{* *}$ & 1 & $.940^{* *}$ & $.769^{* *}$ \\
\hline & Sig. (2-tailed) & .000 & & .000 & .000 \\
\hline & $\mathrm{N}$ & 163 & 163 & 163 & 163 \\
\hline \multirow{3}{*}{ Material Management } & Pearson Correlation & $.583^{* *}$ & $.940^{* *}$ & 1 & $.752^{* *}$ \\
\hline & Sig. (2-tailed) & .000 & .000 & & .000 \\
\hline & $\mathrm{N}$ & 163 & 163 & 163 & 163 \\
\hline \multirow{3}{*}{ Material Quality } & Pearson Correlation & $.806^{* *}$ & $.769^{* *}$ & $.752^{* *}$ & 1 \\
\hline & Sig. (2-tailed) & .000 & .000 & .000 & \\
\hline & $\mathrm{N}$ & 163 & 163 & 163 & 163 \\
\hline
\end{tabular}


From the results of above Table XII, there is significant, moderate and positive relationship between building construction material waste management and material cost $(r=0.532, p<0.05)$. However, Material Price related factor has more relationship when we compare with the correlation results of Material waste managements' with respect to building construction material cost with value of $r=0.658$ and $p<0.05$. Also from the results of the above correlation the relationships of Material Price related factor with building construction material cost is approximately equal with the relationship that Design effects has with building construction material cost $(r=0.680, p<0.05)$. On the other hand, there is strong positive relationship between Building construction Material management and Building construction material cost $(\mathrm{r}=$ $0.820, \mathrm{p}<0.05)$. This value is the second magnitude as shown in the above table XII, when it compared with the relationships of the others independent variables with Building material cost. Finally from above correlation results, the relationships of Workmanship (material usage) with Building construction material cost is the first in magnitude $(\mathrm{r}=0.825, \mathrm{p}<0.05)$, that mean it has the strongest relationships with material cost than the others variables.

As depicted on the second table XIII of correlation result, there are three major variables identified that can affects Building construction material quality from which two of them affects both Building construction material cost and Building construction material quality. These variables are Building construction Workmanship /Material usage/ and Building construction Material management that have value of correlation results with Building construction material quality, $(\mathrm{r}=$ $0.769, \mathrm{p}<0.05)$, and $(\mathrm{r}=0.752, \mathrm{p}<0.05)$ respectively. This value indicated that both variables have significant, strong and positive relationships with Building construction material quality. On the other hand correlation result also shown that there is significant, strong and positive relationships between building construction material quality and Building construction material Specification $(\mathrm{r}=0.806, \mathrm{p}<0.05)$. This shown it's the first value in magnitude of the three variables with Building construction material cost, as well as it has the strongest relationships with Building construction material cost.

Generally, all variables are statistically significant at 95\% confidence level implies that at 5\% level of confidence, and it is assessed that all of the independent variables are positively related to Building Construction material cost and quality. In other words the increase or decrease of independent variables correlated directly with the increase or decrease of the dependent variables that are Building construction material cost and quality. Hence, the correlation results indicates two of five major independent variables (workmanship first and Material management second in magnitude) have strongly correlated with material cost as well as three of five independent variables (design effects third, Material Price related factor fourth and material waste management fifth, when ranked based on their correlation results magnitude) are moderately correlated with Building construction material cost. Finally, three of major independent variables (specification, Workmanship and Material management magnitude) are strongly correlated with Building construction material quality.

\subsubsection{Multi-linear Regression Model Analysis}

According to Ho (2006), multiple regression analysis is used to predict the values of a dependent variable given the values of two or more independent variables by calculating a regression equation.

The general multiple regression equation assumes:

$\mathrm{Y}=\beta_{0}+\beta_{1} \mathrm{X}_{1} \ldots+\beta \mathrm{nXn}+\varepsilon$

Where, $\mathrm{Y}$ is dependent variable which Building construction material cost and quality and $\mathrm{X} 1, \mathrm{X} 2, \mathrm{X} 3$...Xn is the independent variables, $\beta_{0}$ is constants, $\beta$ is unstandardized regression coefficient and $\varepsilon$ is error terms.

Five independent variables (Waste management, Material Price related factor, Workmanship, Material Management and Design effects) which were hypothesized to have influence on the first dependent variable (Building construction material cost), and Three independent Variables (Specification, Workmanship and Material management) which were hypothesized to have influence on the second dependent variable (Building construction material quality) were included under multivariate model analysis.

TABLE XIV

MULTI-COLLINEARITY DIAGNOSTICS OF FIRST MODEL

\begin{tabular}{l|l|l}
\hline \multirow{2}{*}{ Variables } & \multicolumn{2}{|l}{ Collinearity Statistics } \\
\cline { 2 - 3 } & Tolerance & VIF \\
\hline Material Waste Management & .743 & 1.347 \\
\hline Material Price related factor & .586 & 1.705 \\
\hline Material Management & .113 & 8.860 \\
\hline Workmanship & .110 & 9.096 \\
\hline Design Effects & .591 & 1.691 \\
\hline
\end{tabular}


TABLE XV

MULTI-COLLINEARITY DIAGNOSTICS OF SECOND MODEL

\begin{tabular}{l|l|l}
\hline \multirow{2}{*}{ Variables } & \multicolumn{2}{|l}{ Collinearity Statistics } \\
\cline { 2 - 3 } & Tolerance & VIF \\
\hline Specification & .626 & 1.598 \\
\hline Workmanship & .111 & 9.019 \\
\hline Material Management & .117 & 8.554 \\
\hline
\end{tabular}

Before running the multi regression models all the hypothesized explanatory variables were checked for the existence of multicollinearity problem. When the predictor variables are correlated among themselves, the unique contribution of each predictor variable is difficult to assess. This is because of the overlapped or shared variance between the predictor variables, i.e., they are multicollinear. If the values of Tolerance less than 0.10 and the value of VIF (Variance of inflation factor) are greater than 10 there is a multicolinarity problem (Ho, 2006). In this study Table XIV and Table XV Showed that both the "tolerance" values (greater than 0.10) and the "VIF" values (less than 10) are all quite acceptable. Thus, multicollinearity did not seem to be a problem for this study.

TABLE XVI

MODEL SUMMARY OF FIRST MODEL

\begin{tabular}{l|l|l|l}
\hline $\mathrm{R}$ & R Square & Adjusted R Square & $\begin{array}{l}\text { Std. Error of the } \\
\text { Estimate }\end{array}$ \\
\hline $.878^{\mathrm{a}}$ & .771 & .764 & .29632 \\
\hline
\end{tabular}

Predictors: (Constant), Design Effects, Material Waste Management, Material Price related factor, Material Management, Workmanship

\section{TABLE XVII MODEL SUMMARY OF SECOND MODEL}

\begin{tabular}{|c|c|c|c|}
\hline $\mathrm{R}$ & R Square & $\begin{array}{ll}\text { Adjusted } & \mathrm{R} \\
\text { Square } & \\
\end{array}$ & $\begin{array}{l}\text { Std. Error of the } \\
\text { Estimate }\end{array}$ \\
\hline $.881^{\mathrm{a}}$ & .777 & .773 & .30130 \\
\hline
\end{tabular}

Predictors: (Constant), Material Management, Specification, Workmanship

The above regression results revealed that the relationship between the observed values of Building construction material cost and linear combination of the independent variables (Waste management, Material Price related factor, Workmanship, Material management and Design effects) as well as the relationship between the observed values of Building construction material quality and linear combination of the independent variables (Specification, Workmanship, Material management).

According to Ho, 2008, a measure of the strength of the computed prediction equation is R-square, sometimes called the coefficient of determination. If all the observations fall on the regression line, R-square is 1 (perfect linear relationship) and An R-square of 0 indicates no linear relationship between the predictor and dependent variables. In this research from Table XVI and Table XVII, model summaries of ' $\mathrm{R}$ square' values, the first model /model of dependent variable Building construction material cost/ $\mathrm{R}$ square $=0.771$ and the second model /Model of dependent variable Building construction material quality/ $\mathrm{R}$ square $=0.777$. This indicated both values closer to 1 , and this shown us there were strong linear relationship between the variables. Further, the $\mathrm{R}$ square value of the first model 0.771 indicated that the linear relationship between the Independent variables (Waste management, Material Price related factor, Workmanship, Material management and Design effects) explains $77.1 \%$ of the variance of Building construction material cost. The remaining unexplained $22.90 \%$ could be due to other factors that were not considered in the study. Also, the value of the second model 0.777 indicated that the linear relationship between the Independent variables (Specification, Workmanship, Material management) explains $77.7 \%$ of the variance of Building construction material quality. The remaining unexplained $22.30 \%$ could be due to other factors that were not considered in the study. 


\section{TABLE XVIII \\ REGRESSION RESULT COEFFICIENTS OF FIRST MODEL}

\begin{tabular}{|c|c|c|c|c|c|}
\hline \multirow[t]{2}{*}{ Variables } & \multicolumn{2}{|c|}{ Unstandardized Coefficients } & \multirow{2}{*}{\begin{tabular}{|l|}
$\begin{array}{l}\text { Standardized } \\
\text { Coefficients }\end{array}$ \\
Beta \\
\end{tabular}} & \multirow[t]{2}{*}{$\mathrm{T}$} & \multirow[t]{2}{*}{ Sig. } \\
\hline & B & Std. Error & & & \\
\hline (Constant) & -.091 & .101 & & -.900 & .370 \\
\hline Material Waste Management & .134 & .046 & .128 & 2.884 & .004 \\
\hline Material Price related factor & .193 & .054 & .178 & 3.563 & .000 \\
\hline Material Management & 267 & .118 & .258 & 2.270 & .025 \\
\hline Workmanship & .276 & .117 & .272 & 2.366 & .019 \\
\hline Design Effects & 211 & .047 & 221 & 4.449 & .000 \\
\hline
\end{tabular}

Dependent Variable: Material Cost

TABLE XIX

REGRESSION RESULT COEFFICIENTS OF SECOND MODEL

\begin{tabular}{|c|c|c|c|c|c|}
\hline \multirow[t]{2}{*}{ Variables } & \multicolumn{2}{|c|}{ Unstandardized Coefficients } & \multirow{2}{*}{$\begin{array}{l}\text { Standardized } \\
\text { Coefficients } \\
\text { Beta }\end{array}$} & \multirow[t]{2}{*}{$\mathrm{T}$} & \multirow[t]{2}{*}{ Sig. } \\
\hline & $\mathrm{B}$ & Std. Error & & & \\
\hline (Constant) & -.125 & .097 & & -1.295 & .197 \\
\hline Specification & .647 & .057 & .534 & 11.269 & .000 \\
\hline Workmanship & .250 & .118 & .238 & 2.111 & .036 \\
\hline Material Management & .234 & .117 & .218 & 1.993 & .048 \\
\hline
\end{tabular}

Dependent Variable: Material Quality

The Table XVIII indicated the multiple linear regression coefficient estimates including the intercept and the significance levels. Two multiple linear regressions were established in this study for material cost and quality.

The first regression equation for material cost was developed:

$Y_{1}=-0.091+0.134 W M+0.193 M P+0.267 M M+0.276 W p+0.211 D E$

Where: $\mathrm{Y}_{1}=$ Material cost

$\mathrm{WM}=$ Waste Management

MP = Material Price

$\mathrm{MM}=$ Material Management

$\mathrm{Wp}=$ Workmanship

$\mathrm{DE}=$ Design Effects

For every additional of each independent variables, Building construction material cost increases by the value of their beta coefficient in this equation. The significances and the direction of the independent variables are expressed as: Waste management is significant at $(\beta=.134, \mathrm{t}=2.884, \mathrm{p}<.05)$, Material Price related factor $(\beta=.193, \mathrm{t}=3.563, \mathrm{p}<.05)$, Material Management $(\beta=.267, \mathrm{t}=2.270, \mathrm{p}<.05)$, Workmanship $(\beta=0.276, \mathrm{t}=2.366, \mathrm{p}<.05)$,Design effects $(\beta=.211, \mathrm{t}=4.449$, $\mathrm{p}<.05)$. These results shown as all the independent variables were significant and had positive effect on the Building construction material cost. In the same way, the Table XIX showed the multiple linear regression coefficient estimates including the intercept and the significance levels.

Hence, the second regression equation for material quality was developed:

$$
\mathrm{Y}_{2}=-0.125+0.647 \mathrm{Sp}+0.250 \mathrm{Wp}+0.234 \mathrm{MM}
$$

Where: $\mathrm{Y}_{2}=$ Material Quality 


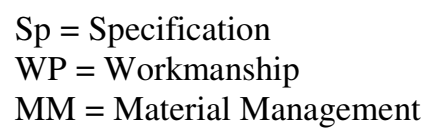

On behalf of every additional of each independent variable, Building construction material quality increases by the value of their beta coefficient in this equation. The significances and the direction of the independent variables expressed as: Specification $(\beta=.647, \mathrm{t}=11.269, \mathrm{p}<.05)$, Workmanship $(\beta=.193, \mathrm{t}=2.111, \mathrm{p}<.05)$ and Material Management $(\beta=.250, \mathrm{t}$ $=1.993, \mathrm{p}<.05)$. These results shown as all the independent variables were significant and had positive effect on the Building construction material quality.

According to Ho, 2008, the standardized beta coefficient's of predictor variables shows the contribution that an individual independent variable makes to the model. This means the size of the Beta weights indicates the strength of their independent relationships. Hence, since all predictors variables (independent variables) are positive and significant we can rank the strength of their impacts on dependent variable (Building Construction Material cost) based upon the sequences of the size of their standardize beta as: Workmanship is the first $(\beta=.272)$, Material Management the $2^{\text {nd }}(\beta=.258)$, Design effects the $3^{\text {rd }}$, Material Price related factor $4^{\text {th }}(\beta=.221)$ and Waste management $5^{\text {th }}(\beta=.178)$. Also, in the same way we can rank the strength and the effects of the predictors (independent variables) in the second model had on dependent variable (Building construction material quality) as: Specification the $1^{\text {st }}(\beta=.534)$, Workmanship the $2^{\text {nd }}(\beta=.238)$ and Material Management the $3^{\text {rd }}(\beta=.218)$. This all revealed that the effects of each independent variable had on both dependent variables that mean Building construction material cost and quality.

The R- square results confirmed with the results of the study concluded by Ayodeji (2006) that affirmed poor quality of materials and workmanship has a very high and positive effect on building collapse in Nigeria with the value of $\mathrm{R}=0.95$. The study conducted in Nigeria by Zubairu(2016) validated that the main factors affecting quality management of building construction firms include; inadequacy of site personnel, adequate knowledge of project, poor material quality and poor quality of professionals and workmanship. On the other hand Otim., et,al., (2011) also found that the causes of material wastages on sites were found to include; poor supervision of operatives, poor handling of materials, misuse of materials, poor storage and stacking of materials, delivery of excess material on site, poor site organization, late delivery of materials, poor coordination of management and technical side, poor time management, bad weather conditions, use of unskilled operatives.

\subsubsection{Summary of the findings}

Generally, Factors affecting Building construction material cost and quality on building construction projects was identified as: Workmanship/Material Usage/, Material Management, Design Effects, Material Price related factors, Waste Management and Specification. From these all factors, except the Specification were identified as the major factors that had effects on Building construction material cost, and ranked based the weight of their effects. The researcher identified that Workmanship /Material Usage/ and Material Management were the factors that affects both Building construction material cost and Building material quality. Hence, the Specification, Workmanship /Material Usage and Material Management were the major factors that identified and ranked based on the effects they had construction material quality.

The established models results revealed that the relationship between the observed values of Building construction material cost and Building construction material quality, with the linear combinations of their independent variables, and determined a measure of the strength of the computed prediction equations which is called R-square. Two multi-linear regression models were established in this research for both dependent variables that mean Building construction material cost control and Building construction material quality control in which all predictors /independent variables/ were significant, positive direction and, had the values of R-square 0.771 and 0.777 respectively. This value of the computed prediction equation /R-square/ indicated that there was strong relationship between the dependent variables with their respective predictors, and strong effects of predictors on dependent variables.

\section{CONCLUSIONS}

The objectives of the research were to identify the different factors affecting the materials cost and quality on building construction site, to rank and analyze the major factors that tends to affect the cost and quality of materials used for building project from the different groups of respondents and to establish a model to optimize materials cost and materials quality using multi-linear regression method. To achieve these objectives, the researcher used Interview and questionnaire survey as research instruments. The information gathered from the survey was analyzed using Relative importance index, spearman's correlation coefficient and multi-linear regression method. The identified major factors were Workmanship /Material Usage, Material Management, Design Effects, Material Price related factor and Waste Management were major factors affect Building construction material cost, while Specification, Workmanship /Material Usage/ and Material Management were the identified factors affecting Building construction material quality. From these identified factors Workmanship /Material Usage/ and Material Management were identified as they were affecting both Building construction material cost and Building construction material quality. The correlation analysis indicated all variables are statistically significant at $95 \%$ confidence level implies that at 5\% level of confidence, and it is assessed that all of the independent variables are positively related to Building Construction material cost and quality. On the other hand the degree of factors of variables ranked 
depends up on the Relative Importance Index and the top ranked and key factors were identified under all major variables as follows:

- Sufficient Training of workers/staff on how to reduce waste of building construction materials $(\mathrm{RII}=0.876)$ ranked 1st , Waste management plans and using it (RII=0.840) ranked 2nd and Loss and damage of materials $(\mathrm{RII}=$ 0.829) ranked 3rd were the most factors affecting Building construction Material Waste Management on project work

- $\quad$ Proper forecasting of materials price in the market $(\mathrm{RII}=0.850)$ ranked 1 st, Inflation $(\mathrm{RII}=0.835)$ ranked $2 \mathrm{nd}$ and Fluctuation in money exchange rates $(\mathrm{RII}=0.823)$ ranked 3rd were the most factors affecting Building construction Material price on project work.

- Using suitable, safe and secure storage $(\mathrm{RII}=0.886)$ and Congestion of sites $(\mathrm{RII}=0.886)$ ranked 1 st while Attention to weather condition $(\mathrm{RII}=0.821)$ ranked $2 \mathrm{rd}$ were the most factors affecting Building construction Material management on project work

- Quality checking for each delivery of the aggregates to the site from the sources (RII $=0.889)$ ranked 1 st, Inspection and Verification of materials quality $(\mathrm{RII}=0.826)$ ranked $2 \mathrm{nd}$, and the steel reinforcement stored for a long period of time exposed to weather $(\mathrm{RII}=0.826)$ ranked 3rd were the key factors affecting Building construction Material standard and specification on construction sites.

- $\quad$ Poor cutting of materials (glass, tiles, plywood), $(\mathrm{RII}=0.870)$ ranked 1st, Rework due to improper quality and mistakes $(\mathrm{RII}=0.827)$ ranked 2 nd and Inadequate skill in utilization of materials $(\mathrm{RII}=0.811)$ ranked 3rd were the most factors affecting Building construction Material usage/workmanship/.

- Design changes (change introduced by client $)(\mathrm{RII}=0.770)$ ranked 1st, Design conformance to codes and standards $(\mathrm{RII}=0.767)$ ranked 2nd and Complete drawing design and specification $(\mathrm{RII}=0.755)$ ranked 3rd were the most factors concerning Design that affecting Building construction Material on construction project works.

- Material Wastage minimization $(\mathrm{RII}=0.908)$ ranked 1 st, Planning and monitoring construction activities $(\mathrm{RII}=$ 0.867) ranked 2nd and proper workmanship (RII $=0.859$ ) ranked 3rd were the key factors affecting Building construction Material cost on construction project work. On the other hand Planning and monitoring construction activities $(\mathrm{RII}=0.867)$ ranked 1 st, Proper workmanship $(\mathrm{RII}=0.859)$ ranked 2nd and Satisfaction of Clients $(\mathrm{RII}=$ 0.817) ranked 3rd were the key factors affecting Building construction Material quality on construction project work.

- All predictors/independent variables/ were significant and had strong positive relationship with dependent variables. The values of R-square were 0.771 and 0.777 for material cost and material quality respectively. This revealed as there was strong linear relationship between the dependent variables with their respective predictors, and strong effects of predictors on dependent variables.

\section{ACKNOWLEDGMENT}

The authors express their profound gratitude to Ambo University Hachalu Hundessa, Institute of Technology for all supports during research activities.

\section{REFERENCES}

Abdul Rahman, H., Thompson, P. A. and Whyte, I. L. (1996). Capturing the Cost of Non Conformance on Construction Sites- An Application of the Quality Cost Matrix, . International Journal of Quality \& Reliability Management, 13(1), 1996, 48-60.

Adebayo, S. (2000). Improving building techniques. Proceedings of a workshop on Building collapse: Causes, prevention and remedies (pp. pp. 48-51). Lagos State.: The Nigeria Institute of Building.

Agyerum, K. (2012). Minimizing Materials Wastage at The Construction Stage of a Project through the implementation of lean construction. A Thesis submitted to the Department of Building Technology, Kwame Nkrumah University of Science and Technology, pp, 11-12.

Ahmed, Z. (2017). The impact of material management on construction project delivery in Maldives. A dissertation submitted in partial fulfilment of the requirements for the award a Master of Project Management, 14.

Ajibade, A. (2009). Devaluation of Naira Will Stifle the Economy. The Nation Newspaper.

Ali, A. S. and Wen, K. H. (2011). Building Defects: Possible Solution for Poor Construction Workmanship. Journal of Building Performance, 2(1), 59-69.

Alsen Fromsa, Woyesa Ararsa, Emer Tucay Quezon. Effects of Poor Workmanship on Building Construction and Its Implication to

Project Management Practice: A Case Study in Addis Ababa City. Xi'an Dianzi Keji Daxue Xuebao/Journal of Xidian University. Volume

14, Issue 9, 2020, https://doi.org/10.37896/jxu14.9/128

Arditi, D and Gunaydin, H .M. (1997). Total quality management in the construction process . International Journal of Project Management, 15 (4) 235-243.

Arditi, D and Gunaydin, H .M. (2004). Total quality management in the construction process. Illinois Institute of Technology, Department of Civil and Architectural Engineering, Chicago, IL, US , 60616.

Arditi, D., and Lee, D. E. (2004). Service quality performance of design/build contractors using quality function deployment. Construction Management and Economics , 22(1), 123-127.

Arditi, D., Tarim Akan, G., and Gurdamar, S. (1985). Cost overruns in public projects. Journal of Project Management, Vol. 3, No. 4, Butterworth \& Co. Ltd., London , 218-224. 
Asmara Seyoum Joro. (2015). Managing and Management of Construction Materials on Selected Public Building projects in Addis Ababa. Addis Ababa University, 27.

Bekele Sitota, Emer T. Quezon, Woyesa Ararsa. Assessment on Materials Quality Control Implementation of Building Construction Projects and Workmanship: A Case Study of Ambo University. Xi'an Dianzi Keji Daxue Xuebao/Journal of Xidian University. Vol. 15(8): (2021), 138-155. https://doi.org/10.37896/jxu15.8/013.

Binyam Letarge, Emer T. Quezon, Yolente C. Macarubbo; Evaluation on the Performance of Lowest Responsive Bid Contract and the Quality of Materials Used on Governmental Building Projects in Jimma Town, IJSER, Volume 7, Issue 12, December-2016, pp 6073 .

Bitew, D. (2019). Assessment of Quality management practices in construction projects: the case of AACRA. A Research Project Submitted in Partial Fulfilment of the Requirements for the Award of the Degree of Masters of Project Management, 24.

Booz Allen \& Hamilton Inc. and DRI/McGraw-Hill. (1995). The transit capital cost index study. Federal Transit Administration (July 17, 2011).

Boxer, L. (2004). Cost of quality management. International Journal for Quality research , 64-76.

Burati, J. L., Michael, F. M., Satyanarayana, N. K. (1992). Quality management organizations and techniques. Journal of Construction Engineering and Management , 118(1), 112- 128.

Butler J.B. (1982). Element of Administration for Building Student. Great Britain: Anchors press Ltd.

Callahan, J. T. (1998). Managing transit construction contract claims, Transportation Research Board, Transportation cooperative research program synthesis 28. National Academy Press, Washington, D.C , 1-59.

Carr, R. I. (1989). Cost-estimating principles. Journal of Construction Engineering an Management , ASCE 115(4), pp. $545-551$.

Central Statistical, A. (2008/09). Report on Contract construction survey. The Federal Democratic Republic of Ethiopia.

Chan, A and Chan, A. (2004). Factors Affecting the Success of construction project. Journal of Construction Engineering and management , 135-5.

Chang, A. S. (2002). Reasons for cost and schedule increases for engineering design projects J. Manage. Eng., 18(1), 29-36.

Chitkara, K. K. (2005). Construction Project Management: Planning, Scheduling, and Controlling. Tata : McGraw Hill Publishing Company Ltd.

Chung, H. (1999). Understanding Quality Assurance in Construction, A practical guide to ISO 9000 for contractors. University of Technology Sydney: e-library.

Conway, H. C. (2005). Construction. New York: A Report on the Industry submitted to Industrial College of the Armed Forces National Defense University.

Cooke, B., Wiliams, P. (2004). Construction Planning, Programming \& Control, 2nd edition,. Great Britain: Blackwell Publishing Ltd.

Dainty, A.R.J., Briscoe, G.H. and Millet, S.J. (2001). New perspectives on construction supply chain integration. Supply Chain Management: An International Journal , 6(4), pp. 163-173.

Damnjanovic, I. (2008). How reliable are Estimates of Infrastructure Costs? A Comparative Analysis. Texas: Department of Civil Engineering A\&M University.

Dharwadker, P. P. (1996). Construction Management, 2nd Ed. New, Delhi. India.: Oxford \& IBH Publishing Co. PVT. LTD.

Doyle, D. (1994). ISO 9000 Quality Systems Handbook. London: Butterworth.

Drew, D. and Skitmore, M. (2001). The effect of client and type and size of construction work on a contractor's bidding strategy. Building and Environment, Vol. 36, 393-406.

Emer Tucay Quezon, and Arthur G. Ibanez, "Effect of Covid-19 Pandemic in Construction Labor Productivity: A Quantitative and Qualitative Data Analysis." American Journal of Civil Engineering and Architecture, vol. 9, no. 1 (2021): 23-33. doi: 10.12691/ajcea-9-1-4

Emer Tucay Quezon, and Arthur G. Ibanez. Analysis of influential factors affecting workers' productivity on highway construction projects during Covid-19 pandemic in Cagayan Valley Region, Philippines. Global Journal of Engineering and Technology Advances. 2021; 6(2): 074-089: https://doi.org/10.30574/gjeta.2021.6.2.0019

Ferguson, H. and Clayton, L. (Eds). (1998). Quality in the Constructed Project. A Guideline for Owners, Designers and Constructors . New York: 1. ASCEA.

Flyrbjerg, B. (2005). Policy and planning of large infrastructure project problems, causes, cures. World Bank policy research working paper, 3781 .

G. Kanimozhi, P. Latha. (2014). Material Management in Construction Industry. Indian Journal of Applied Research, 4(4), pp. 1-3 .

George Otim, Fiona Nakacwa, Michael Kyakula. ( 2011). Cost Control Techniques Used On Building Construction Sites in Uganda. Second International Conference on Advances in Engineering and Technology, (pp. pp 267-373). Uganda.

Gunaydin, H. M. (1995). Masters Thesis, Illinois Institute of Technology, Chicago, IL. TQM in the Construction Industry.

Hailemariam Kassu, Eyob Mekonnen, Dumesa Gudissa, Emer T. Quezon; Correlation Analysis of Factors Affecting Shoring Construction Techniques in Central Business District of Addis Ababa, Ethiopia; Xi'an Dianzi Keji Daxue Xuebao/Journal of Xidian University, ISSN No:1001-2400, VOLUME 14, ISSUE 10, 2020, 692-706, https://doi.org/10.37896/jxu14.10/074

Harbuck, R. (2004). Competitive Bidding for Highway Construction Projects. Morgantown, W. Va: Association for the Advancement of Cost Engineering International Transactions.

Hendrickson, C. (1998). Project Management for Construction. Pittusburgh ,PA 15213: Carnegie Mellon University.

Henson, H and C. Newton. (1995). Tools and Methods for Identifying Skill Shortages: Across Country comparison. Ottawa: Human Resources Development Canada, Applied Research Branch, Occupational Projects and Macroeconomic Studies.

Ho, R. (2006). Handbook of univariate and multivariate data analysis and interpretation with SPSS. Parkway NW: Chapman \& Hall/CRC, Taylor \& Francis Group.

Hufschmidt, M. M., and Gerin, J. (1999). Systematic errors in cost estimates for public investment projects. Columbia, New York: The analysis of public output, J. Margolis, ed.

Juran, J. M. (1988). Juran's Quality Control Handbook, 4th edition. New York: McGraw-Hill.

Juran, J. (1999). Quality control handbook (5th ed.). New York: McGraw-Hill.

Kerzner, H. (2009). Project Management . in New York: tenth edition.

Ledbetter, W. B. (1990). The quality performance management system, A blue print for implementation. Austin, TX: Publication 10-3, Construction Industry Institute.

Li, H. (2009). Study on Construction Cost of Construction Projects. Asian Social Science , 4. 
Lukman, O. O., Babatunde, E. J. and Moshood, O. f. (2011). Design Factors Affecting Building Projects in Nigeria, Consultants Perception. Singapore: Annual Report Department of Building, National Open University.

Melese Mengistu, Emer T. Quezon, Getachew Kebede; Assessment of Factors Affecting Labor Productivity on Road Construction Projects in Oromia Region, Bale Zone. IJSER, Vol. 7, Issue 11, November 2016 Edition, 899-910.

Merrow, E. W. (1988). A quantitative analysis of very large civilian projects. New York: Rand, Santa Monica, Calif.

Moavenzadeh, F. and Rossow, J. A. K. (1995). The Construction Industry in Developing Countries. Massachusetts: Technology Adaptation Program, Massachusetts Institute of Technology.

Molenaar, K. (2005). Programmatic Cost Risk Analysis for Highway Megaprojects. Journal of Construction Engineering and Management , 131(3):345-57.

N.B. Kasim, C.J. Anumba, and A.R.Jand A.R.J. Dainty. (2005). Improving Materials Management Practices On Fast-Track Construction Projects. Proceedings, ARCOM Twenty First Annual Conferences (pp. pp. 793-802). London: SOAS.

Narimah Kasim, A. A. (2013). RFID Technology for Materials Management in Construction Projects - A Review. International Journal of Construction Engineering and Management Faculty of Technology Management \& Business Universiti Tun Hussein Onn Malaysia, Johor 86400,Malaysia , pp,7-8.

Nevile, A. (1985). Properties of concrete. O.S Ademeso: Longman Scientific and Technical.

Oberlender, G. D. (1993). Project Management for Engineering and Construction . New York: McGraw Hill.

Ogunsemi, D. R. (2002). Cost and Time Performance of Construction Projects in South western Nigeria. A PhD. thesis submitted to the School of Postgraduate Studies, Federal University of Technology Akure .

Oke, A. E. (2006). Effect of quality of materials and workmanship on building collapse in Nigeria. Ondo state in Nigeria: Federal University of Technology, Akure.

Omange, G. N. and Udegbe, M. I. (2000). Government Involvement in Housing. Nigeria: In effective Housing in the 21st Century.

Palaneeswaran, E., Ng, T and Kumaraswamy, M. (2006). Client Satisfaction and Quality Management Systems in Contractor Organisations. Building and Environment, 41 (11) 1557-1570.

Patel, K. (2011). Construction Materials Management on Project Site. National Conference on Recent. India Trends in Engineering \& Technology.

Patil, A. R. \& Pataskar, S. V. (2013.). Analyzing Material Management Techniques on Construction Projects. International Journal of Engineering and Innovative Technology (IJEIT) , 3(4), pp. 96-100.

Pickrell, D. H. (1992). A desire named streetcar: Fantasy and fact in rail transit promotions and evaluation. J. Am. Plann. Assoc , 58(2), $158-176$.

Popescu, M.C., Phaobunjong, K., and Ovararin, N. . (2001). Estimating Building Costs 1st edition. United States of America: Marce Dekker, Inc., .

Raftery, J. (1991). Principles of Building Economics. Osney Mead, Oxford OX2 0EL, UK: BSP Professional Books A division of Blackwell Scientific Publications Ltd.

Sadiwala, R. C. (2006). Material and financial. New age training international Publishers, pp. 15-30.

Sanderson, V. (2006). Current Strategies to Address Increasing Highway Construction Costs and Reduced Competition. Technical Agenda. Washington, D.C: AASHTO Subcommittee on Construction.

Serkalem Molla, Emer T. Quezon, Eyob Mekonnen, Woyesa Ararsa, Dumesa Gudissa, and Anteneh Tibebu; Factors Affecting the Performance in the Implementation of Government Building Construction Projects: A Case Study in Bole Sub- City of Addis Ababa. Xi'an Dianzi Keji Daxue Xuebao/Journal of Xidian University, ISSN No:1001-2400, VOLUME 14, ISSUE 11, 2020, ISSUE 11, 2020, 247-256, https://doi.org/10.37896/jxu14.11/020

Shen, V. T. (2002). Material wastage in construction activities a Hong kong survey. Department of Building \& Real Estate, The Hong Kong Polytechnic University, Hong Kong, pp,2.

Smallwood J. and Rossouw J. (2008). The implementation of quality management systems in South African construction. Proceedings of the Royal Institution of Chartered Surveyors Construction and Building Research conference (COBRA). Republic of Ireland: held at Dublin Institute of Technology.

Smith, S. (1988). How to Take Part in the Quality Revolution: A Management Guide. London: PA Management Consultants.

Stewart, R. (1982). Cost estimating. NY: John Wiley \& Sons.

Thomas, H.R. and Riley, D.R., and Messner, J.R. ( 2005). Fundamental Principles of Site Material Management. Journal of Construction Engineering and Management , 131(7), $808-815$.

Touran, A., Bolster, P. and Thayer, S. (2004). Risk Assessment in Fixed Guideway Construction. Washington, D.C: Report No. FTA-MA26-0022, U.S. Dept. of Transportation.

Udeh, C. (1991). Contract Administration in Nigeria Proceedings of the . International Conference on Quantity Surveying and Developing World. Nigeria: ABU Zaria.

Vaxevanidis, N.M., \& Petropoulos, G. . (2008). Cost of quality models (COQ) and implementation. International Journal for Quality research , 583-626.

Wasiu, A. B., Aliu, A. and Modupe, A. . (2012). An Assessment of Implementation of Quality Culture in Construction. Lagos: Department of Building, University of Lagos.

Willar, D. (2012). Improving Quality Management System Implementation in Indonesian Construction Companies. (Published Doctorial Thesis) Department of Civil Engineering Queensland University .

Woodrow, W. (2002). Bridge project bridge superstructure contract (BR-3). Review of the engineer's estimate vs. the single bid .

Yonas Ketema, Emer T. Quezon, Getachew Kebede; Cost and Benefit Analysis of Rigid and Flexible Pavement: A Case Study at Chancho -Derba-Becho Road Project. IJSER, Vol. 7, Issue 10, October 2016 Edition, 181-188.

Yosef Amare, Emer T. Quezon, Mamuye Busier; Causes of Delays during Construction Phase on Road Projects due to the Failures of Contractor, Consultant, and Employer in Addis Ababa City Road Authority, IJSER, Vol. 8, Issue 3, March-2017 Edition, 15-25. 